OPEN ACCESS

Edited by:

James J. Kobie,

University of Alabama at Birmingham, United States

Reviewed by:

Zehua Sun,

University of Pittsburgh, United States

Premkumar Lakshmanane,

University of North Carolina at Chapel

Hill, United States

*Correspondence:

Chiranjib Chakraborty

drchiraniib@yahoo.com

Sang-Soo Lee

123sslee@gmail.com

${ }^{\dagger}$ These authors have contributed equally to this work

Specialty section:

This article was submitted to

Viral Immunology,

a section of the journal

Frontiers in Immunology

Received: 25 October 2021

Accepted: 05 January 2022

Published: 09 February 2022

Citation:

Chakraborty C, Sharma AR, Bhattacharya M and Lee S-S (2022) A Detailed Overview of Immune Escape, Antibody Escape, Partial Vaccine

Escape of SARS-CoV-2

and Their Emerging Variants

With Escape Mutations.

Front. Immunol. 13:801522.

doi: 10.3389/fimmu.2022.801522

\section{A Detailed Overview of Immune Escape, Antibody Escape, Partial Vaccine Escape of SARS-CoV-2 and Their Emerging Variants With Escape Mutations}

\author{
Chiranjib Chakraborty ${ }^{1 * t}$, Ashish Ranjan Sharma ${ }^{2 \dagger}$, Manojit Bhattacharya ${ }^{3}$ \\ and Sang-Soo Lee ${ }^{2 *}$
}

\footnotetext{
${ }^{1}$ Department of Biotechnology, School of Life Science and Biotechnology, Adamas University, Kolkata, India, 2 Institute for Skeletal Aging and Orthopedic Surgery, Hallym University-Chuncheon Sacred Heart Hospital, Chuncheon-si, South Korea,

${ }^{3}$ Department of Zoology, Fakir Mohan University, Vyasa Vihar, Balasore, India
}

The infective SARS-CoV-2 is more prone to immune escape. Presently, the significant variants of SARS-CoV-2 are emerging in due course of time with substantial mutations, having the immune escape property. Simultaneously, the vaccination drive against this virus is in progress worldwide. However, vaccine evasion has been noted by some of the newly emerging variants. Our review provides an overview of the emerging variants' immune escape and vaccine escape ability. We have illustrated a broad view related to viral evolution, variants, and immune escape ability. Subsequently, different immune escape approaches of SARS-CoV-2 have been discussed. Different innate immune escape strategies adopted by the SARS-CoV-2 has been discussed like, IFN-I production dysregulation, cytokines related immune escape, immune escape associated with dendritic cell function and macrophages, natural killer cells and neutrophils related immune escape, PRRs associated immune evasion, and NLRP3 inflammasome associated immune evasion. Simultaneously we have discussed the significant mutations related to emerging variants and immune escape, such as mutations in the RBD region (N439K, L452R, E484K, N501Y, K444R) and other parts (D614G, P681R) of the S-glycoprotein. Mutations in other locations such as NSP1, NSP3, NSP6, ORF3, and ORF8 have also been discussed. Finally, we have illustrated the emerging variants' partial vaccine (BioNTech/Pfizer mRNA/Oxford-AstraZeneca/ BBIBP-CorV/ZF2001/Moderna mRNA/Johnson \& Johnson vaccine) escape ability. This review will help gain in-depth knowledge related to immune escape, antibody escape, and partial vaccine escape ability of the virus and assist in controlling the current pandemic and prepare for the next.

Keywords: immune escape, vaccine escape, SARS-CoV-2, escape mutation, variants 


\section{INTRODUCTION}

After detecting SARS-CoV-2 in Wuhan, the world is currently passing through a very crucial pandemic station. Infections have spread throughout the globe. Millions of people have died. School, colleges and universities are closed. The situation is a significant challenge for the world economy. It has been noted that vaccination is one of the tangible ways to fight against the pandemic. Therefore, every country has started a COVID-19 vaccination program to vaccinate the people and fight against the pandemic $(1,2)$. At the same time, scientists noted different new variants of SARS-CoV-2, affecting various epidemiological phenomena of the pandemic. Some significant variants have been entitled as Variants of Concern/Variants of Interest (VOC/ VOI) status due to their superior risk with more severity and amplified transmissibility (3-6). These VOC/VOI possess mutations imparting properties like an immune escape and reduced vaccine efficacy to this virus (7). Due to the added devastating effects of the SARS-CoV-2 variants, Boehm et al. describe the present conditions as pandemics within the pandemic because of the spread of these variants (8).

Several significant variants of SARS-CoV-2 have emerged during one and half years due to the mutations. Some are entitled as VOC/VOI by CDC (US), and WHO, among the variants. Major VOCs are B.1.1.7 (Alpha), P.1 (Gamma), B.1.427/B.1.429 (Epsilon), B.1.351 (Beta), B.1.617.2 (Delta), which contains different significant mutations in the S-glycoprotein. Few mutations include K417T/N, E484K, L452R, N501Y, P681R, D614G, etc. $(3,9)$. At the same time, some significant VOIs are circulating in different parts of the world, which are B.1.526, B.1.525, P.2, P.3, B.1.617.1 $(3,10)$. Several mutations have been observed among VOI, and some common mutations are K417T/ N, E484K, L452R, N501Y, P681R and D614G. However, most of the mutations were noted as deleterious mutations in genomes sampled from the mutant variety of the SARS-CoV-2, circulating throughout the world $(5,11)$. It has been observed that several characteristics of the virus may have been changed due to these mutations. Some prominent biological functions that might have changed are infectivity, re-infectivity, pathogenicity, antigenicity, and transmissibility (3). One of the crucial mutations was the D614G mutation in the S-glycoprotein, which was noted in the early phase of the pandemic in $2020(8,12,13)$. Kim et al. first reported this novel mutation of D614G, and they concluded that this mutation might be responsible for altered antigenicity and immunogenicity. They also stated that further detailed studies would be needed in this direction (12). At the same time, Eaaswarkhanth et al. raised a question about this mutation and a link between elevated COVID-19 mortality. They concluded that $\mathrm{D} 614 \mathrm{G}$ substitution might be responsible for higher COVID-19 mortality (14). Similarly, several other significant mutations occur in the S-glycoprotein, which are accountable for the change of the biology of this virus. However, more researches are needed about the important mutations of these SARS-CoV-2 emergences of variants. It will help to understand the mechanism in changing the biological feature of SARS-CoV-2 due to the mutations.
All viruses can mutate, which helps the virus to evade the human immune system and cause infection and re-infection (infecting the same patient twice or more) to the human. The phenomenon is called viral escape $(15,16)$. This occurrence is one of the significant barriers to antiviral therapy and vaccine development. During this pandemic, the researcher has observed the emergence of SARS$\mathrm{CoV}-2$ variants rapidly through evolution. Some of these variants are associated with the appearance of immune escape. Understanding the emergence of new variants is genuinely required for controlling this virus (17).

It has been noted that the variants of SARS-CoV-2 arrived rapidly throughout the globe. Some of the early identified variants were observed in Brazil and South Africa, naturally showing the immune evasion characteristics (18). Now, SARSCoV-2 mutants are dominant strains in several regions of the world. Some mutations of these variants are related to immune escape or partial vaccine escape of SARS-CoV-2. The two mutations are noted in the RBD (receptor-binding-domain) related to immune escape. These mutations are K417N/T and E484K (19). Another mutation in the S-glycoprotein region is D614G, which is associated with immune escape (20). At the same time, vaccine escape is another problem due to the ongoing development of the new SARS-CoV-2 variants. Thus, more immunological studies are required to understand the immune escape mechanism and partial vaccine escape mechanism of these variants of SARS-CoV-2.

This manuscript provides a detailed overview of immune and partial vaccine escape of the emerging variants with escape mutations. We first illustrated a general view related to viral evolution, viral variants, and immune escape in this direction. Next, we discussed different immune escape strategies of SARS$\mathrm{CoV}-2$, primarily innate immune escape approaches such as IFN1 production dysregulation, cytokines related immune escape, immune escape associated with Dendritic cell (DC) function and macrophages, Natural Killer (NK) cells related immune escape, neutrophils related immune escape, pattern-recognition receptors (PRRs) associated immune evasion and NLRP3 inflammasome related associated immune evasion. Likewise, we have discussed the significant mutations in emerging variants for immune escape. In this direction, we illustrated the mutations in the RBD region (N439K, L452R, E484K, N501Y, K444R) and other regions (D614G, P681R) of the S-glycoprotein. We have also discussed mutations at different locations such as NSP1, NSP3, NSP6, ORF3, and ORF8. Finally, we discussed antibody escape and partial vaccine escape of emerging variants. Vaccine evasion of BioNTech/Pfizer mRNA vaccine, Oxford-AstraZeneca vaccine, BBIBP-CorV vaccine, ZF2001 vaccine, etc., have been highlighted. Our updated review will help researchers strategize and control the pandemic situation.

\section{VIRAL EVOLUTION, VIRAL VARIANTS, AND IMMUNE ESCAPE: OVERVIEW}

Viral mutations are common in nature. This common phenomenon is a part of a virus life cycle in practicality (21). 
Due to elevated mutation rates, more genetic diversity develops in viruses. Deleterious mutations are noted in most cases of the virus as a part of the evolution process and natural selection, maximum being in RNA viruses (22). Similarly, natural selection might favor beneficial mutations or combinations. In contrast, the recombination process might help to retain genetic diversity (23).

On the other hand, the mutation rate is a significant criterion to understand the evolution process of the virus $(24,25)$. A high rate of evolution is noted in several viruses. The high mutation rate is one of the significant factors, along with generation times and population size, which attribute high evolutionary rate of viruses. However, it was observed that mutation accumulation or individual mutations might benefit or harm survival. This incidence causes genetic processes that can produce even new species or drive towards endangered species (26). It has been noted that the mutation rates in RNA viruses are more compared to DNA viruses (27). Mutation of virus creates viral variants. A high mutation rate might generate several viral variants in a limited time $(25,28)$. One recent example is the generation of SARS-CoV-2 variants. Pachetti et al. identified mutations in the $R d R p$ gene of this virus. They have found several mutations in the $R d R p$ gene and identified predominant mutations in a region-specific manner. They observed mutation in 2891, $23403,3036,14408$, and 28881 locations in the $R d R p$ gene from Europe. At the same time, some mutations, such as 17746, and 18060 are observed in North American regions isolated from SARSCoV-2 strains (28).

Similarly, several researchers have reported the mutations of the hepatitis B virus, which might have created variants of this virus. At the same time, researchers noted that these mutations have several clinical implications $(29,30)$. Likewise, several mutations have been noted for the influenza virus during evolution, which has created several influenza virus variants $(31,32)$.

Immune escape is a phenomenon when the host immune system is incapable of responding against an infectious agent, and the process is also called immune evasion or antigenic escape (15). It has been noted that the immune escape process occurs during the evolution process of the virus and helps the virus in its survival (33). Some specific mutation helps to achieve the process of immune escape, and these mutations are called immune escape mutations $(5,15,34,35)$.

Several researchers have tried to illustrate the immune escape mechanism for various viruses (Table 1). Rosenberg tried to discuss the immune escape mechanism for viral hepatitis (68). Thimme et al. described the different immune escape approaches of the hepatitis C virus (69). At the same time, Lhomme et al. described the different immune escape strategies to neutralize the innate immunity of the hepatitis E virus (70). Vossen et al. represented the immune evasion of virus in the light of viral evolution. In this case, they have described the strategies to counteract the immune response into three divisions: cellular immune response, humoral immune response, and immune effector functions (71).

Due to viral fitness, it has been noted that immune escape develops in the virus. Many factors can help establish viral fitness, and one of the factors is mutational effects. Viral fitness might reduce the vaccine efficacy for some viruses through immune escape. Therefore, this area is a significant challenge nowadays because it can also describe the immune evading mechanism against vaccines (72).

Uebelhoer et al. have described that viral fitness is related to the mutations linked with the escape of cytotoxic T cells. The researchers noted two immune escape mutations, which are L1637P, and L1637S (73). Song et al. have described the role of immune escape mutations on HIV-1 fitness. They also discussed the role of escape mutation, $\mathrm{T} 242 \mathrm{~N}$, in replication fitness and R355K mutation for early CTL escape (74). Recently, Majumdar and Niyogi described the different mutations of SARS-CoV-2 and the implications of the mutations on viral fitness (75).

\section{SARS-CoV-2 AND DIFFERENT IMMUNE ESCAPE STRATEGIES}

After viral infection, the first line of defense mechanism tries to apply the mechanisms for viral clearance through the components of innate immunity. The component of the line of defense machinery includes a range of immune cells, a group of cytokines, interferons, and physical barriers. The immune cells include NK cells, DCs, etc. (76-78). Physical barriers for innate immunity include skin, mucosa, mucus, mucous membranes, earwax, tears, and stomach acid provide preliminary clearance. These physical barriers offer a defense mechanism against invading viruses $(79,80)$. The lungs are exposed to the virus frequently. Martin and Frevert describe the first line of defense mechanism in the lungs. The mucus layer, airway epithelial cells, alveolar macrophages, innate lymphoid cells, and DCs provide the first line of defense mechanism in the lungs (81). This lung defense mechanism is first exposed to the SARS-CoV-2 and other respiratory viruses such as coronaviruses $(\mathrm{CoV})$, respiratory syncytial virus (RSV), influenza virus, and rhinoviruses. After crossing the defense mechanism, the pattern-recognition receptors (PRRs) try to recognize the virus components. PRRs are also a part of innate immunity $(82,83)$. Presently, it has been observed that three classes of PRRs are engaged to recognize virus components. These PRRs are Toll-like receptors (TLRs), a retinoic acid-inducible gene I (RIG-I)-like receptors (RLRs), and NOD-like receptors (NLRs). It has also been noted that the two receptors (TLRs and RLRs) play a significant role in the production of various cytokines and type I interferons (IFNs) during virus infection. At the same time, NLRs regulate the production of IL$1 \beta$ (interleukin-1 $\beta$ ) and its maturation process through the caspase- 1 activation process (84).

\subsection{Innate Immune Escape Approaches of SARS-CoV-2}

SARS-CoV-2 adopts several innate immune escape strategies (Figure 1). Some innate immune escape strategies are discussed in the respective sections:

\subsubsection{IFN-I Production Dysregulation and Immune Escape} The SARS-CoV-2 infection causes the production dysregulation of different types of IFN (Figure 2). It has been observed that 
TABLE 1 | Different approaches for immune escape by other viruses are observed from time to time.

\begin{tabular}{|c|c|c|c|}
\hline Strategies & Virus & Remarks & References \\
\hline \multirow[t]{7}{*}{$\begin{array}{l}\text { Intervention with PRRs } \\
\text { signaling }\end{array}$} & Vaccinia virus & $\begin{array}{l}\text { A46R protein targets to multiple Toll-like-interleukin-1 receptor adaptors } \\
\text { component }\end{array}$ & $(36)$ \\
\hline & Hepatitis C virus & $\begin{array}{l}\text { NS5A protein inhibits TLR mediated signaling by combining with MYD88, } \\
\text { Extracellular vesicles cover dsRNA of hepatitis C virus to reduce activation of TLR3 }\end{array}$ & $(37,38)$ \\
\hline & Enterovirus (EV) & $\begin{array}{l}\text { Viral proteinases 3Cpro and 2Apro neutralizes the PRRs signaling pathway by } \\
\text { targeting RIG-I and MDA5 protein. }\end{array}$ & $(39,40)$ \\
\hline & Influenza A virus & $\begin{array}{l}\text { NS1 proteins of the virus impound viral dsRNA to escape from the sensing by } \\
\text { PRRs }\end{array}$ & $(41)$ \\
\hline & Hepatitis B virus & $\begin{array}{l}\text { Escape away from the cyclic GMP-AMP (cGAMP) synthase enzyme action by the } \\
\text { packaging of the viral genome within the capsid segment }\end{array}$ & $(42)$ \\
\hline & Ebola virus and Marburg virus & $\begin{array}{l}\text { VP35 protein interact with viral dsRNA genomes to prevent viral sensing by RIG-1 } \\
\text { and MDA- } 5 \text { proteins. }\end{array}$ & $(43)$ \\
\hline & SARS-COV & $\begin{array}{l}\text { Papain-like protease antagonized the TLR7 signaling pathway by the removing of } \\
\text { Lys63-linked polyubiquitination of TNF receptor-associated factors }\end{array}$ & $(44)$ \\
\hline \multirow[t]{3}{*}{$\begin{array}{l}\text { Overcoming the physical } \\
\text { barrier }\end{array}$} & $\begin{array}{l}\text { Dengue virus, Zika virus and West } \\
\text { Nile virus }\end{array}$ & Break the skin barrier via permissive cells infection & $(45)$ \\
\hline & $\begin{array}{l}\text { Adenovirus, swine vesicular disease } \\
\text { virus, reovirus, Coxsackie virus }\end{array}$ & Pass through mucosa by targeting the apical junctional proteins complex & $(46)$ \\
\hline & $\begin{array}{l}\text { Simian immunodeficiency virus and } \\
\text { human immunodeficiency virus }\end{array}$ & Enter the physical barrier in numerous ways & $(47)$ \\
\hline Transcriptional factors (IRF3/7, & SARS-CoV & M protein of virus stops the activation of IRF3/7 by targeting TBK1/IKK+ & $(48)$ \\
\hline \multirow[t]{8}{*}{ NF-kB, and AP1) inhibition } & Human papilloma virus 16 & E6 oncoprotein from virus binds to IRF3, which inhibits self-transcriptional activity & (49) \\
\hline & Ebola virus & VP35 protein stops IRF3 phosphorylation and later dimerization & $(50)$ \\
\hline & Enterovirus & Viral 3C proteases cut the IRF7 protein & $(51)$ \\
\hline & Vaccinia virus & Viral proteins A46, A49, A52, inhibit the NF-kB activation by various mechanisms. & $(52)$ \\
\hline & Human papillomavirus & $\begin{array}{l}\text { Ubiquitination of IRF-3 upstream and NFkB by upregulating the UCHL1 protein by } \\
\text { cellular deubiquitinase }\end{array}$ & $(49)$ \\
\hline & Influenza A viruses & NS1 protein prevents the nuclear translocation of NF-kB and IRFs & $(53)$ \\
\hline & MERS-CoV & $\begin{array}{l}\text { ORF8b encoded protein suppresses TBK1 and MDA5 regulated NF-kB signaling } \\
\text { and M protein stop the TBK1-dependent phosphorylation event of IRF3 }\end{array}$ & $(54,55)$ \\
\hline & SARS-CoV-2 & $\begin{array}{l}\text { Inactivation of TRAF3 and stop the subsequent activation of IRF3/7 and NF-kB } \\
\text { protein }\end{array}$ & $(56)$ \\
\hline \multirow[t]{3}{*}{$\begin{array}{l}\text { Antagonizing of Interferon- } \\
\text { stimulated gene }\end{array}$} & HIV-2 & $\begin{array}{l}\text { Antagonize the tetherin protein which interacting with the rod envelope glycoprotein } \\
\text { of virus }\end{array}$ & $(57)$ \\
\hline & MERS-CoV & $\begin{array}{l}\text { NS4b proteins responsible for the enzymatic degradation of OAS-RNase L protein } \\
\text { element }\end{array}$ & $(58)$ \\
\hline & $\begin{array}{l}\text { Hepatitis C virus, Influenza A virus, } \\
\text { Vaccinia virus }\end{array}$ & $\begin{array}{l}\text { Viral proteins (NS1E2/NS5A, Tat, and E3I/K3L) particular viruses interact with PKR } \\
\text { (protein kinase R) }\end{array}$ & $(59)$ \\
\hline \multirow[t]{8}{*}{$\begin{array}{l}\text { Intervention of JAK-STAT } \\
\text { signaling }\end{array}$} & $\begin{array}{l}\text { Porcine reproductive and } \\
\text { respiratory syndrome virus }\end{array}$ & $\begin{array}{l}\text { Nsp11 protein bind with IRF9, and formation of the transcription factor complex } \\
\text { IFN-stimulated gene factor } 3 \text { (ISGF3) for nuclear translocation }\end{array}$ & $(60)$ \\
\hline & Nipah and Hendra virus & $\begin{array}{l}\text { Nucleoproteins prevent the nuclear accumulation of STAT1 and STAT2 proteins } \\
\text { and inhibit with their complex formation }\end{array}$ & $(61)$ \\
\hline & Parainfluenza virus type 1 & $\begin{array}{l}\text { C protein interacts and keeps STAT1 proteins in perinuclear aggregates at the } \\
\text { terminal endosome }\end{array}$ & $(62)$ \\
\hline & Rotavirus & NSP1 protein inhibits the activation of STAT1 protein & (63) \\
\hline & Mumps virus & V protein stimulate the degradation of STAT-1 and STAT-3 proteins & (64) \\
\hline & Herpes Simplex Virus & Inhibition of JAK-STAT signaling pathway by inducing SOCS3 protein & $(65)$ \\
\hline & Zika virus & The viral NS2B3 protein stimulates the degradation of Jak1 protein & (66) \\
\hline & Human papilloma virus types 18 & E6 oncoprotein of virus interacts with Tyk2 and stop the JAK-STAT activation & $(67)$ \\
\hline
\end{tabular}

some kinds of IFNs production (IFN-I and -III) were reduced during infection of SARS-CoV-2 (85). It has been illustrated that type III IFN has a significant role in controlling the SARS-CoV-2. Stanifer et al. described that type III IFN might hinder the SARSCoV-2 life cycle, thereby preventing the infection of this virus in hIECs (Human Intestinal Epithelial Cells). Therefore, interferon might be efficient in controlling the SARS-CoV-2 replication (86). However, due to the decrease or dysregulation in the IFN production, SARS-CoV-2 replication was increased. Lei et al. noted that this virus-induced an aberrant type-I IFN response in the culture cells. It might cause delayed type-I IFN responses, resulting in the evasion of type-I IFN. At the same time, Sprotein and NSP2 did not show the same result (87). In contrast, Rebendenne et al. have tried to illustrate that the IFN response was incapable of controlling the replication of the virus in lung cells. However, elevated levels of IFNs produced were observed in lung cells after the infectivity of SARS-CoV-2. They reported a high level of type-I and III IFN where the IFN response was mediated through MDA-5. It has been noted that interferon production was induced to the MDA-5 associated sensing of this virus in lung epithelial cells. Thus, it might be unsuccessful in controlling the virus replication in epithelial cells in the lungs 


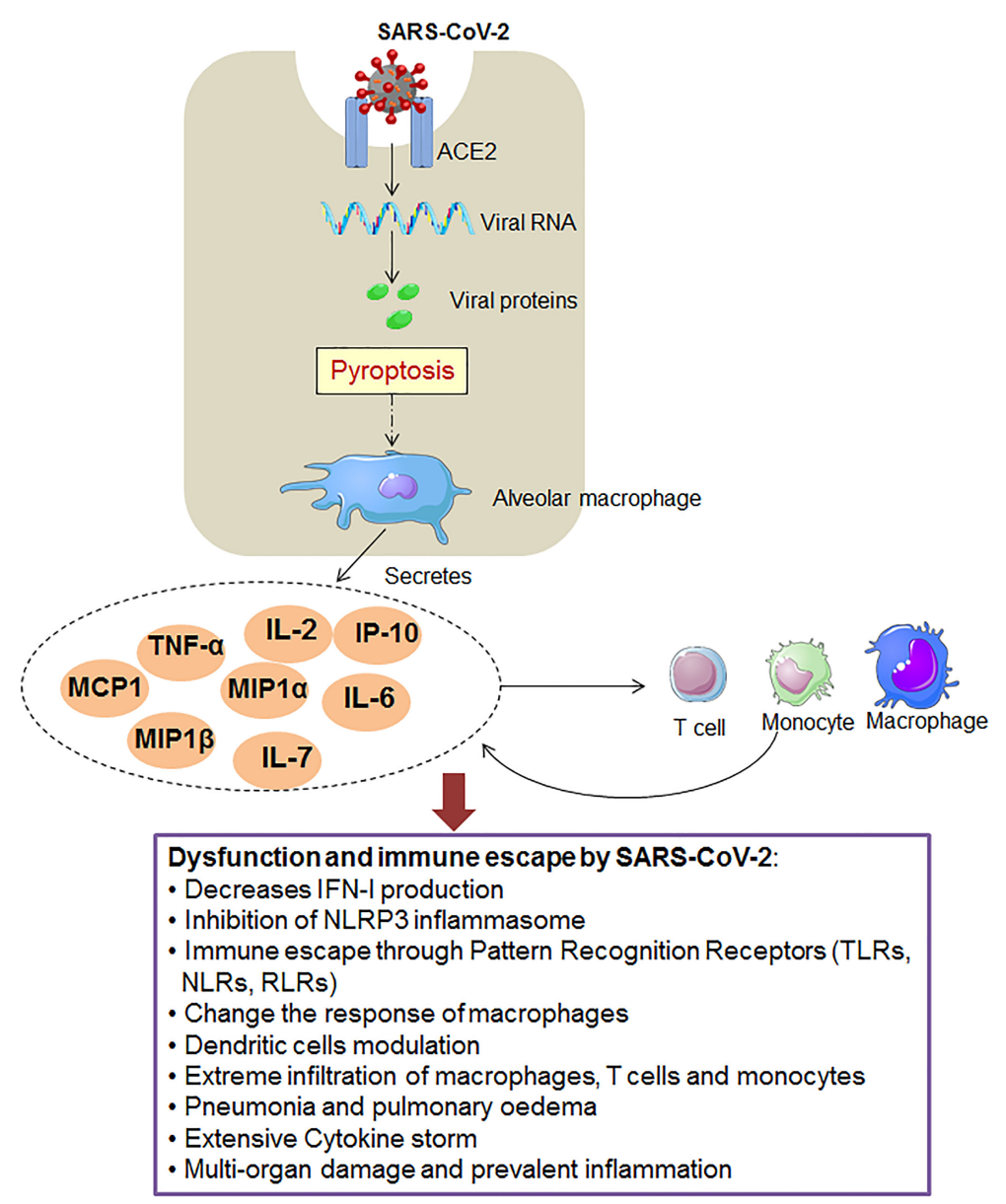

FIGURE 1 | The figure shows the SARS-CoV-2 that adopts different innate immunity evasion strategies for immunity evasion.

(88). Miorin et al. illustrated that this virus could inhibit STAT1 nuclear translocation, obstructing IFN signaling. They have reported that Orf6 can interact with the Nup98-Rael complex straightforwardly. This Orf6 protein can help in the localization of the NPC (nuclear pore complex), which suppresses interferon signaling (89). Recently, Sa Ribero et al. explained the interplay between the type-I IFN response and the virus where they have described the suppression of IFN-I induction by the virus. They represented the strategies to counteract and escape IFN-I production (90). At the same time, age-related IFN-1 dysfunction was also observed by the researchers. A sharp decline in IFN-I production was indicated due to age which might cause IFN-1 dysfunction $(91,92)$. We can summarize that this virus is highly susceptible to IFN-I inhibition, and it was reported by several researchers (93-95).

\subsubsection{Cytokines and Immune Escape}

In this case, other than IFN response, other cytokines may dysregulate during the COVID-19 in patients. It has been reported that IL-6 is a major indicator of severe COVID-19 in patients (96). A study conducted with 901 patients observed elevated IL-6 in severe and ICU patients (97). IL-6 might be elevated through the TLR during the COVID-19 infection. However, the mechanism is still unclear (98-100). At the same time, it was noted that the equally pro-and anti-inflammatory cytokines are augmented in COVID-19 patients. The elevated circulatory cytokines include TNF $\alpha$, G-CSF, MCP1, IL-7, IL-10, IL-2, IFN- $\gamma$, etc. (101-103). The elevated circulatory cytokines may cause immune dysregulation, and they might help the virus to evade immune responses.

\subsubsection{Function and Immune Escape}

DC plays a significant role in antigen presentation and cytokine production $(104,105)$. DC has a major role in $\mathrm{T}$ cell responses $\left(\mathrm{CD}^{8+}\right.$ and $\mathrm{CD}^{4+} \mathrm{T}$ cell population) in COVID-19 patients (106109). One recent study noted that a loss of DCs function might lead to delayed immune responses. The study indicated that SARS-CoV-2 infection causes DC and $\mathrm{T}$ cell responses impairment. The study has significance in the pathogenesis of the virus, extended viral transmission, disease severity, and susceptibility for future re-infection (110). It is one of the immune escape strategies adopted by SARS-CoV-2. Amino- 


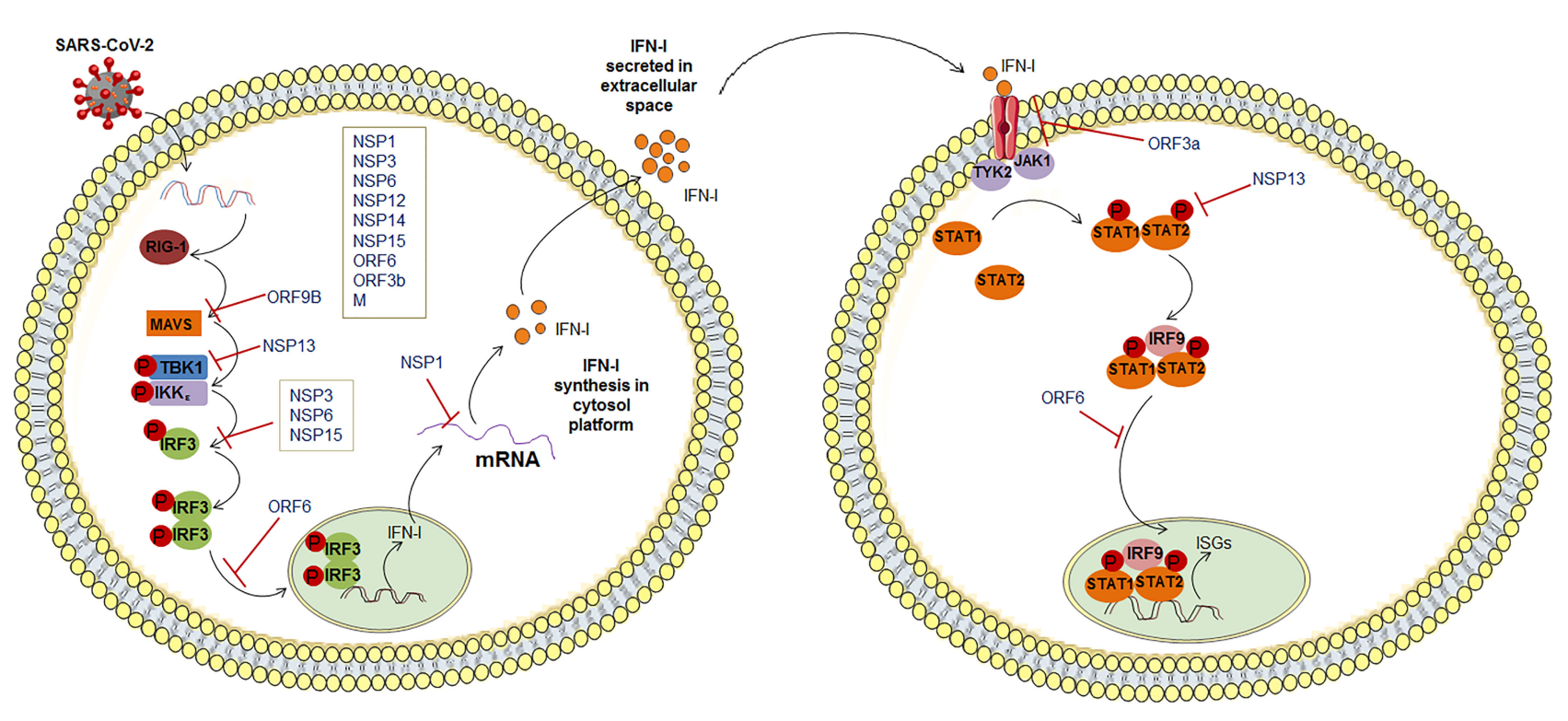

FIGURE 2 | SARS-CoV-2 innate immune evasion by interfering with the IFN signaling pathway.

bisphosphonates can be used to treat severe COVID-19 disease. Brufsky et al. illustrated that amino-bisphosphonates could act as DC modulators and thus can be detrimental to the ability to trigger T cells (111). Moreover, it has been observed that this virus may infect DCs and hamper the maturation of DC, restricting $\mathrm{T}$ cell-mediated responses (Figure 3) $(85,112)$. Therefore, DC cells have a role in COVID-19 infection progression and immune escape.

\subsubsection{Macrophages and Immune Escape}

Another significant component of innate immunity is the macrophages. This immune cell plays an essential role during the pathogenesis of SARS-CoV. However, during SARS-CoV infection, researchers found an altered response of macrophages. Liu et al. found that s-IgG results in repeal wound healing and causes a decrease in the production process of TGF- $\beta$. This phenomenon affects the activation process of classical macrophages and the prolonged activation of classical macrophages, finally leading to severe lung injury (113). Sometimes, inflammatory macrophages accumulation is lethal to the SARS-CoV infection. Channappanavar et al. found that inflammatory macrophage with monocyte and dysregulation of IFN-I causes fatal pneumonia during the infection of SARSCoV (114).

Similarly, macrophages can play a significant role in COVID19 infection along with the MERS and SARS-associated coronavirus infection (115). However, macrophage subtypes play an essential role in the severity of COVID-19. Liao et al. explored the gene expression pattern in macrophage genes in a single-cell landscape in the lungs' alveoli. They observed gene expression patterns in different macrophages such as M1-like macrophages and M2-like macrophages [alveolar macrophages (AMs)]. They concluded that the proportion of macrophage subtypes and macrophage polarization might play a pivotal role in COVID-19 severity (116).

On the other hand, SARS-CoV-2 might infect macrophages and pass through several processes to evade host immunity by manipulating macrophages $(117,118)$. At the same time, Dalskov et al. illustrated the immune evasion mechanism of SARS-CoV-2 by using AMs. They observed that AMs could not sense the virus (119). Again, Lv et al. illustrated that M1 type AMs help viral spread, and this cell type can uptake this virus. In this case, M1-AMs utilize cellular softness to obtain the SARS$\mathrm{CoV}-2$. Finally, the invading virus gets hold of the endolysosomal functional process to host immune escape (120).

\subsubsection{NK Cells and Immune Escape}

NK cells are a significant part of the immune system, primarily the innate immune system, and they are one of the first lines of defense against infections against the virus. These cells help in the clearance of virus-infected cells $(121,122)$. On the other hand, viruses have adopted several mechanisms to escape NK cell-mediated clearance of the virus. It has been noted that several strategies have been developed by the virus to encounter NK cells. Such methods are i) targeting of NK cell receptors pathways and related ligands, ii) modulation of cytokine-mediated signaling, and iii) apoptosis (123). Such approaches are adopted by different viruses such as dengue virus, influenza virus, HIV, cytomegalovirus, etc.

Along with the other viruses, it has been noted that SARSCoV-2 can also modulate defenses mechanism and cytotoxicity related to NK cells (124). Wang et al. found that the number of NK cells was reduced in the severe stage of SARS-CoV-2 infection. Moreover, $\mathrm{CD}^{4+} \mathrm{T}$ cells were augmented in patients with COVID19 (125). Another study by Wang et al. also showed that NK cells were decreased significantly in several COVID-19 patients (about 

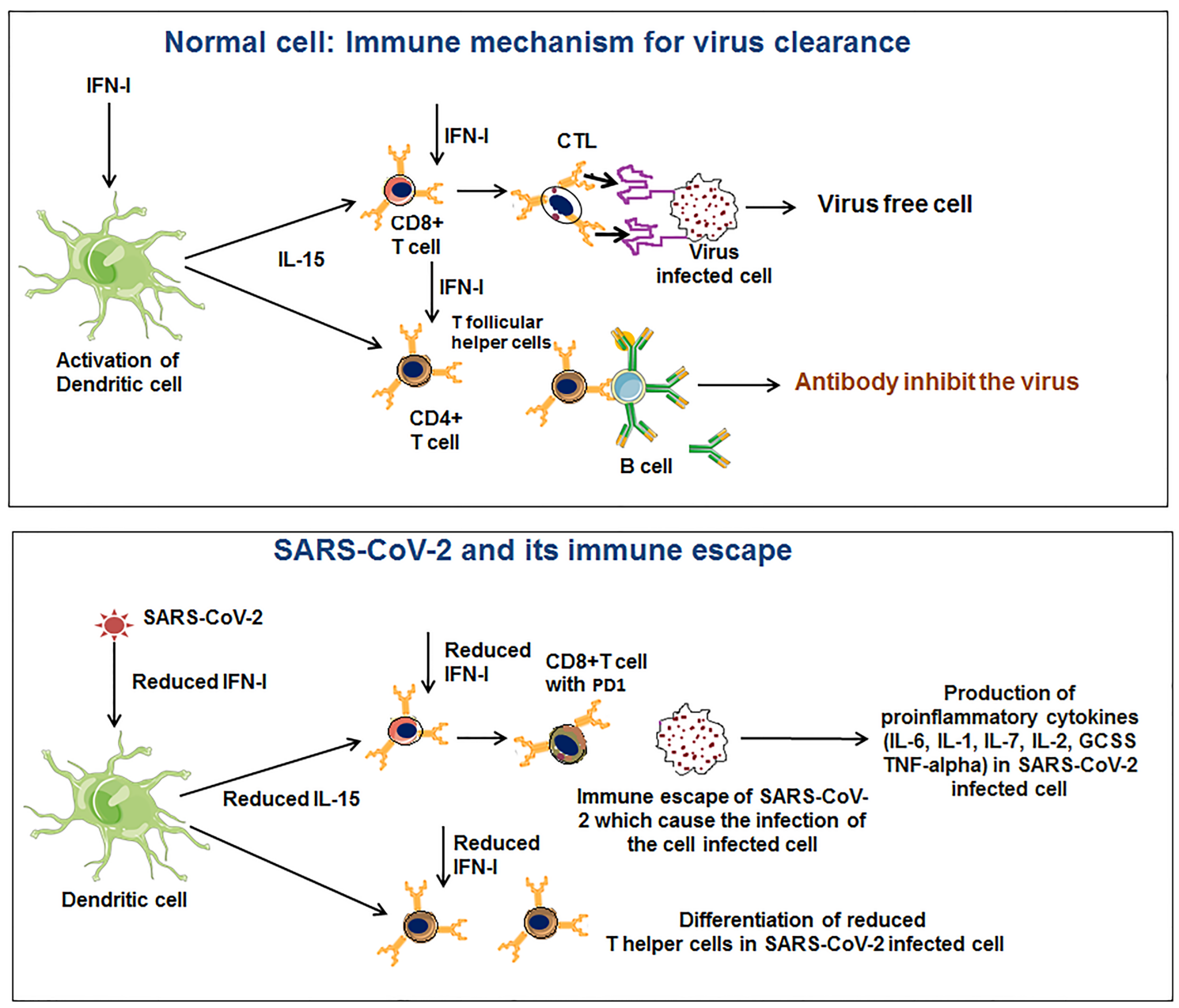

FIGURE 3 | SARS-CoV-2 innate immune evasions through modulation of the dendritic cell (DC) function.

$59 \%$ of the cases) (126). In this study, lower NK cell numbers were correlated to elevated IL- 6 levels in the plasma concentrations of patients infected with the virus. NK-cell immunoglobulin-like receptors (KIR) are expressed on the surface of the NK cell, and these proteins might help evade the host responses through NK cells (127). More studies are needed in this direction to help understand NK cell-related immune escape.

\subsubsection{Neutrophils and Immune Escape}

Neutrophils might be an indicator of viral diseases (128). In different cases, lung neutrophilia is an indicator. However, the relation between the neutrophil pool and COVID-19 is poorly understood. In COVID-19 patients, neutrophils may cause neutrophil extracellular traps (NETs) due to the diseases' pathological effects, which cause organ damage $(129,130)$. Rosa et al. illustrated that neutrophil degranulation and IFN signaling are stimulated during infection of the virus. They found that neutrophil degranulation, genes associated with IFN signaling, and innate immune pathways are considerably induced in the virusinfected macaque lungs (131). At the same time, transcriptional analysis of peripheral blood mononuclear cells (PBMC) and bronchoalveolar lavage fluid (BLF) collected from COVID-19 patients showed that the four genes (LAIR1, CTSD, ADA2, GAA) are involved in neutrophil activation (132). Consequently, an augmented neutrophil-lymphocyte ratio is observed in $80 \%$ of COVID-19 patients (133-135). Therefore, neutrophil activation and accumulation may cause immune dysregulation, and viruses are proficient in escaping immune responses.

\subsubsection{Pattern-Recognition Receptors (PRRs) and Immune Escape}

In general, pattern recognition is instigated by the communications of the genetic materials of a pathogen such as ssRNA/dsRNA/ssDNA/dsDNA, or surface proteins, such TLRs, RLRs, NLRs. The process is also associated with the COVID-19 (136). This virus modulates the PRRs for immune escape and limits IFN, other cytokines, and macrophages. Bickler et al. have evaluated that the PRR gene expression pattern of severe COVID19 patients using genome-wide RNA-seq profiling of human dermal fibroblasts. They have found an association between age 
and augmented PRR gene expression (selected genes) (137). Several scientists are trying to understand the patternrecognition of this viral protein or genomic RNA through TLR or other receptors and immune escape mechanisms using these specific groups of receptors (138-140). The virus might adopt several approaches to escape from the PRRs to immune evading. However, more studies are required to understand the complete immune evading mechanism using PRRs.

\subsubsection{NLRP3 Inflammasome and Immune Escape}

NLRP3 inflammasome is an essential element of the innate immune system, and it activates caspase-1. In the downstream pathway, caspase- 1 converts pro-IL-1 $\beta$ or pro-IL-18 into active forms of IL-1 $\beta$ or IL-18 (141-143). It has been noted that $3 \mathrm{a}$ protein is a significant protein of SARS-CoV-2, synthesized from the ORF3a gene. It is associated with TRAF3. This protein is related to TRAF3 through the TRAF3-binding motif. It has a role in activating the NLRP3 inflammasome and NF- $\mathrm{KB}(144,145)$. After SARS-CoV-2 infection, inflammasomes are activated, and they disseminate efficiently. The massive pyroptosis induces an inflammasome activation mechanism in the epithelial cells. It causes the liberation of an enormous number of virions that cause inflammasome activation $(135,146,147)$. Recently, Zheng et al. have observed that damaged NLRP3 inflammasome activation is directed to inflammatory cell death. It occurs through the RIPK3/caspase-8 pathway and might harm the host (148). At the same time, another study found that overactivation of NLRP3 inflammasome increases fatal occurrence in elderly COVID-19 patients. This study observed age-related overactivation of NLRP3 Inflammasome (149). However, Kim et al. have illustrated that NSP1 and NSP13 of SARS-CoV-2 might inhibit caspase- 1 and inhibit IL-1 $\beta$. This finding shows that the NSP1 and NSP13 can act as significant antagonists of NLRP3-inflammasome (150). Therefore, inhibition NLRP3 inflammasome may help the immune escape of the SARS-CoV-2.

\section{SIGNIFICANT MUTATIONS IN EMERGING VARIANTS AND IMMUNE ESCAPE}

It was noted that initially, the mutation in SARS-CoV-2 was very steady. The rate of evolution was about two mutations every month, which was indicated from December 2019 to October/ November 2020. The phenomenon was evident throughout the globe (151-153). After that, high mutation rates were reported, which has created several emerging variants. Presently, these variants have several significant mutations and are speeding worldwide (3). Several mutations have been found as necessary for immune escape. Some important mutations are recorded from time to time (Table 2) which are discussed as follows:

\subsection{S-Glycoprotein Mutations}

Several important mutations are reported in the S-glycoprotein region (Figures 4,5$)$ from time to time for immune escape:

\subsubsection{D614G}

The D614G mutation got early attention from the researchers. Researchers have noted that the frequency of this mutation started growing in April 2020. Koyama et al. reported this mutation as D614G variants. They found this mutation is frequent in different European countries, such as France, Switzerland, Netherlands, etc. (171). Scientists noted that this mutation shows higher infectivity of the COVID-19 virus (154). Several scientists pointed out that the coding sequence of the mutation (D614G) shows an augmented ratio of $\mathrm{dN} / \mathrm{dS}$. It signifies the positive selection of codon position or the mutation (172-174). Li et al. have described this mutation as highly infectious and affecting antigenicity (175). This mutation increased the affinity to ACE2-binding, leading to maximum cell entry by the virus (176). Mansbach et al. reported that this helps the open state conformation of the S-glycoprotein, which favors

TABLE 2 | Significat mutations are noted in different regions of the SARS-CoV-2 variants, which helps in immune escape.

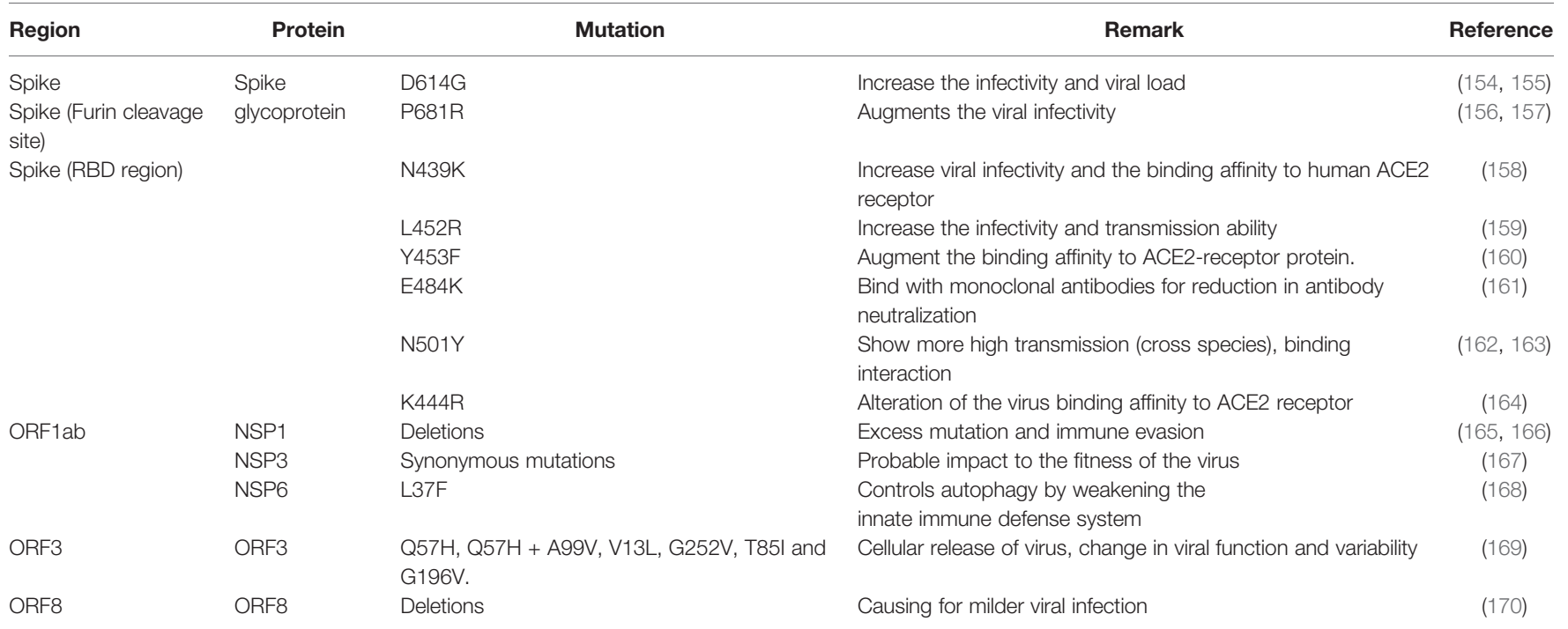



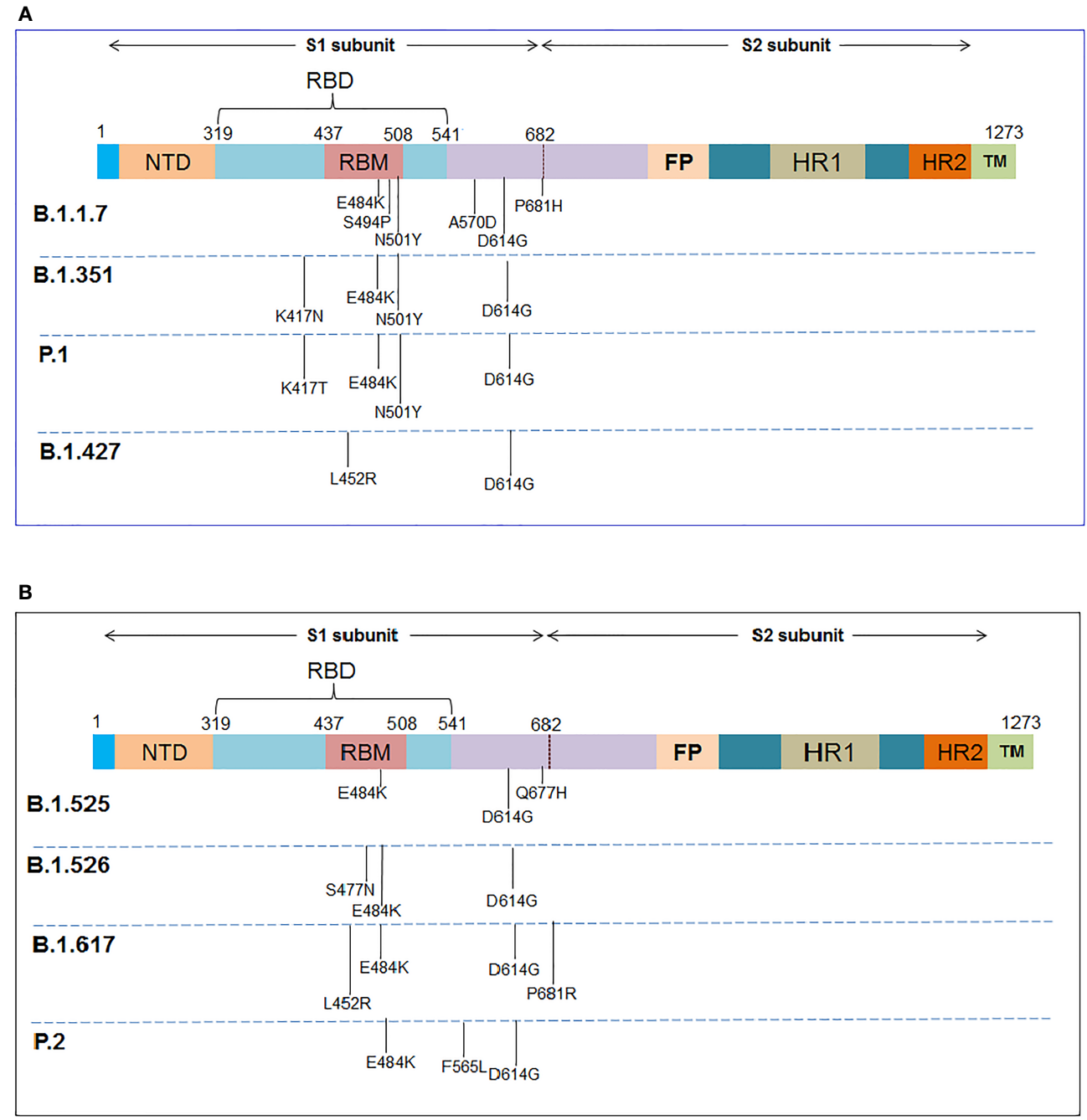

FIGURE 4 | The schematic diagram illustrates the significant mutations in the S-glycoprotein as noted in the VOCs and VOls. (A) Reported essential mutations in the S-glycoprotein of VOCs. (B) Reported critical mutations in the S-glycoprotein of VOls.

the virus in a higher binding rate with the host receptor. They have noted two conformational states of the S-glycoprotein concerning the S-glycoprotein mutation: D-forms (D614) and G-forms (G614). After mutation, G-forms (G614) help the Sglycoprotein's open state and thereby help the maximum extent of interaction with the receptor (155). Daniloski et al. found that this mutation helps multiple cell types in humans and also found that the G-forms (G614) are more proteolytic cleavage resistant. This mechanism might further support the mutated virus to improve the transduction process (177). Due to all these reasons, this mutation is one of the few epidemiologically significant mutations that might help the virus escape the immune system $(3,5,178)$.

\subsubsection{P681R}

This mutation is present in the S-glycoprotein protein near the furin cleavage site. The mutation was observed in the Delta variant (B.1.617.2) and other sublineages of the B.1.617, such as B.1.617.1, B.1.617.3. For the first time, it was noted in variants isolated from India $(156,157)$. This mutation was also reported in Bangladesh (179). The mutation augments infectivity and may help in the immune escape phenomena of the virus.

\subsubsection{Mutation in RBD Region}

\subsubsection{N439K}

The N439K mutation is also noteworthy in S-glycoprotein. The frequency of this mutation was found to increase in some places of Europe in the first quarter of 2020. This mutation occurred due to the amino acid substitution and was found circulating in European countries such as the United Kingdom, Denmark, Germany, Sweden, Switzerland, France, Italy, Iceland, Luxembourg, Norway, and Poland. This mutation is also reported in Asian countries such as Singapore and the Middle East, such as UAE (180-182). This mutation is found in the RBM (receptor-binding 


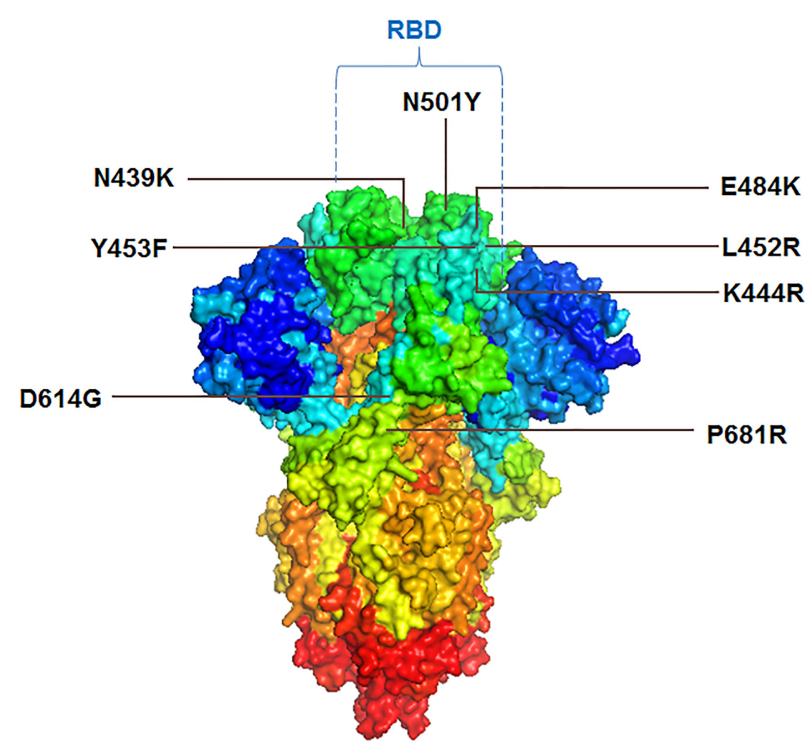

FIGURE 5 | 3D model of S-glycoprotein illustrating the location of significant mutations in the variants, associated with immunity evasion.

motif) and increases the binding affinity to the ACE2 receptor. It is found that this mutated RBD region favor bonding with the hACE2 receptor with an augmented affinity compared to wild-type (158). Therefore, it is an epidemiologically significant mutation, and researchers are focusing on this mutation for further study. It was found that this mutation neutralizes the activity of several mAbs (monoclonal antibodies) $(180,181)$. The mutation may help the virus to evade immunity.

\subsubsection{L452R}

Another significant mutation noted in the RBD region is $\mathrm{L} 452 \mathrm{R}$. It was reported from the variants isolated from several countries such as India (156) and Germany (183). The mutation has been found in several lineages such as Delta, Epsilon, Kappa, Iota, etc. The presence of mutation increases the virus's infectivity and transmission ability. It was found from the antibody neutralization assays that there was a 2.0 -fold decrease in neutralizing titers of post-vaccination plasma (159). Tchesnokova et al. describe that the mutation is associated with a strong positive selection and immune escape (184).

\subsubsection{Y453F}

The Y453F mutation is also significant in the RBD region of Sglycoprotein. This mutation was found to augment the ACE2binding affinity (160). The mutation was observed in a SARSCoV-2 variant (mink-associated and called Cluster 5) (185). The mutation was found in mink (186). It was found that variants with this mutation were transmissible from humans to animals (187). Focosi and Maggi and other researchers have stated that this mutation is an immune escape mutation $(5,188,189)$.

\subsubsection{E484K}

Four mutants were identified at position 484, which are E484K/ E484A/E484G/E484D. It was identified as an immune escape mutation. Among these four mutations, the E484K mutation is a very significant mutation among these mutations. It is noted in the important lineage, such as B.1.1.7 (190). The mutation was observed even in other lineages, which were isolated from different countries such as Japan (R.1 lineage), Germany, USA (B.1.1.345 lineage), Brazil, etc. (191-194). Researchers reported that mutation helps in the immune escape event. Researchers also noted the immune escape phenomenon during Bamlanivimab treatment of COVID19 patients because of E484K mutation. The patients were infected with B.1.1.7 variant (195). Similarly, it was observed that this mutation is associated with the binding of neutralizing Abs, resulting in a reduction in antibody neutralization (161).

At the same time, another significant mutation is the E484D mutation among these four mutations (196).

\subsubsection{N501Y}

The N501Y mutation is considered significant in the RBD region of the S-glycoprotein. It has been noted that the N501Y mutation displayed a more vital interaction between binding to the receptor, ACE2. Tian et al. illustrated additional $\pi$-cation and $\pi-\pi$ interaction for the superior interaction or other force. They also concluded that the mutation with the variants shows more high transmission (163). This mutation also helps cross-species transmission through receptor binding (162). Researchers are working to detect the other variants of this mutation. Sandoval et al. developed a single nucleotide polymorphism assay to identify variants with this mutation (197). This mutation is associated with the process of amino-acid substitutions. Chaintoutis et al. reported that this mutation is associated with immune escape (198). Li et al. also illustrated that this mutation is related to immune escape (199).

\subsubsection{K444R}

Three mutants were identified at 444 positions in the RBD region: K444R, K444Q, and K444N. These mutations were observed in the RBD regions in the emerging viruses. Ortega et al. found that these mutations can change the virus binding affinity to the ACE2 receptor (164). Mutation allows the virus to escape the immune system (166).

\subsection{Mutations in Other Regions}

Several mutations are reported in the other regions excluding Sglycoprotein mutations (Figure 6) which are as follows:

\subsubsection{Mutations in NSP1}

NSP1 permits the virus in immune evasion (200). The mutation was found in different variants circulating in several countries such as Bangladesh (156). Lin et al. have found a deletion in the coding region of Nsp1 $(\Delta 500-532)$. It is associated with lowering the serum IFN- $\beta$ levels of virus-infected patients (201), and it may help the virus to be an immune escape.

Similarly, Benedetti et al. have observed a deletion in position 686-694 with nine nucleotides, resulting in the deletion of three amino acids (AA) to the position of 241-243 AA. However, they associate this phenomenon with decreased viral virulence (165). Therefore, all mutations are not associated with immune or partial vaccine escape in the region. 


\subsubsection{Mutations in NSP3}

Some synonymous mutations were found in this region. NSP3 of the virus is associated with pathogenesis (202), and it may influence the fitness of the virus (167). However, more study is needed to understand the role of NSP3 mutations in immune escape.

\subsubsection{Mutations in NSP6}

Several mutations were observed in the NSP6 region. It has been noted that mutation in the NSP6 region might influence the autophagy of the virus. Therefore, this mutation is implicated in the intracellular survival of the virus and, thereby, the spreading of the virus (203). Similarly, another mutation was reported in the NSP6 at the nucleotide position, 11083, G>T mutation, which results in the mutation L37F. The mutation regulates autophagy by diminishing the innate defense mechanism against the virus (168).

\subsubsection{Mutations in ORF3 Region}

Some mutations are noted in the ORF3 region (204). Bianchi et al. evaluated the mutations in the ORF3 region and found the five most frequent mutations, which are Q57H, Q57H + A99V, V13L, G252V, and G196V. These mutations are associated with interaction with the cellular components and, thus, change in function and variability (169). At the same time, Wang et al. found that the Q57H mutation $(25563 \mathrm{G}>\mathrm{T}$ ) is located in the variants in the USA in high frequency. They also found that the mutation always occurs mutually with mutation 1059C >T-(T85I). Therefore, they concluded that the evolutionary trajectory in terms of time is highly alike (205). Some mutation in the ORF3 protein has been implicated in immune evasion (87).

\subsubsection{Mutations in ORF8 Region}

Some mutations are reported in the ORF8 region. Deletion mutations have been pointed out in the ORF8 part, and Deletion of 382 nucleotides was reported in the ORF8 region. The mutation has clinical implications and might be associated with a milder infection (170). The mutations in the ORF8 region are supposed to be related to immune evasion.

\section{ANTIBODY ESCAPE}

Neutralizing antibodies (nAbs) are one of the significant components for adaptive immunity to neutralize different types of viruses. nAbs can be evoked through vaccination or natural infection (206). It was recently reported that the COVID-19 vaccine elicits immune responses through the nAbs production, and the nAbs may provide protection against the antigenic epitopes of the S-glycoprotein of SARS-CoV-2 (207). Different antibodies have been developed in this direction, and the antibodies are in various stages of development (Table 3). Several scientists reported the nAbs to escape incidents by the SARS-CoV-2 variants and their important mutations, which is a significant concern throughout the globe (Figure 7). Weisblum et al. reported that mutations in the NTD and RBD in Sglycoprotein of variants might confer resistance to $\mathrm{mAb}$ (monoclonal antibodies) from their study. Researchers have used recombinant chimeric virus (VSV/SARS-CoV-2 reporter virus) in this experiment (166).

Similarly, Hoffmann et al. noticed therapeutic antibody escape due to the entry of the two variants (P.1 variant and B.1.351 variant). The researchers found that complete antibody escape phenomena for Bamlanivimab. At the same time, the researchers found that partial antibody escape phenomena for another therapeutic antibody (Casirivimab) (208). Another study reported the Bamlanivimab could be used to treat immunocompromised COVID-19 patients. The E484K mutation might trigger the immune escape phenomena in those immunocompromised patients (192). A recent study noted the antibody escape occurrence with combinations of antibodies. It suggested that novel spike mutants might cause loss of neutralization to the antibody cocktail, representing the escape phenomenon with combinations of antibodies. The researchers used the deep sequencing technique (209). Recently, Greaney et al. reported different mutations in the RBD might escape the binding incidence by diverse classes of antibodies. This study has noted three significant mutations (E484K, K417N/T, L452R) responsible for different categories of antibody escape. They have found that $\mathrm{K} 417 \mathrm{~N} / \mathrm{T}$ is accountable for class 1 antibody escape. The K417N/T mutation is present in two lineages, such as P.1 lineage and B.1.351 lineage. At the same time, the E484K mutation is accountable for class 2 antibody escape. The $\mathrm{E} 484 \mathrm{~K}$ is noted in several lineages such as B.1.526 lineage, P.1 lineage, P.2 and B.1.351 lineages, etc. Similarly, L452R is accountable for class 3 antibody escape. The $\mathrm{L} 452 \mathrm{R}$ is observed in the different lineages such as B.1.617 lineage and B.1.427/429 lineage (210).

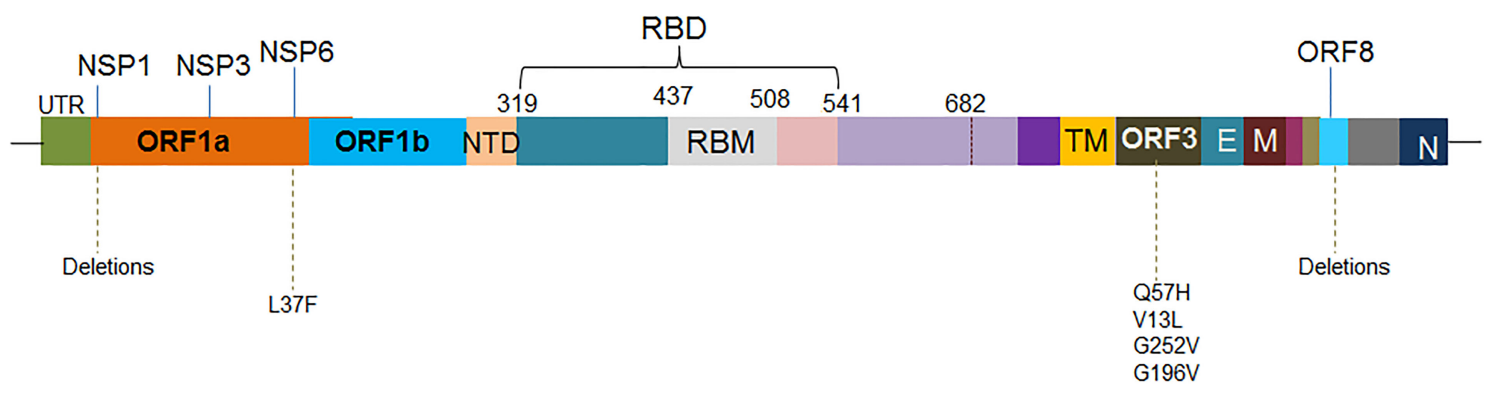

FIGURE 6 | The schematic diagram illustrates the significant mutations in the other region, excluding the S-glycoprotein mutations. 
TABLE 3 | Monoclonal antibodies (mAbs) developed against SARS-CoV-2 for therapeutic purpose which are in preclinical and clinical trial stages.

\begin{tabular}{|c|c|c|c|c|c|}
\hline \multicolumn{2}{|c|}{ Developmental stage } & $\begin{array}{l}\text { SI. } \\
\text { No. }\end{array}$ & $\begin{array}{l}\text { Name and types of } \\
\text { antibodies }\end{array}$ & Target position & Remarks \\
\hline \multirow{10}{*}{\multicolumn{2}{|c|}{ Preclinical }} & 1. & Vh-Fc ab8, human mAb & RBD of S-protein & $\begin{array}{l}\text { Bind to S-protein trimer to neutralized pseudotyped SARS-CoV-2 infections in live } \\
\text { condition }\end{array}$ \\
\hline & & 2. & $\begin{array}{l}\text { Convalescent plasma, } \\
\operatorname{lgG} \mathrm{Ab}\end{array}$ & SARS-CoV-2 & Shown neutralizing activity against to the SARS-CoV-2 infection \\
\hline & & 3. & $\begin{array}{l}\text { P2C-1F11 and P2B-2F6, } \\
\text { human mAb }\end{array}$ & RBD of S-protein & $\begin{array}{l}\text { Bind with ACE2 receptor to interact with RBD, neutralizing pseudotyped and live } \\
\text { SARS-CoV-2 infection }\end{array}$ \\
\hline & & 4. & VIR-7831, human mAb & RBD of S-protein & $\begin{array}{l}\text { Interact with the conserved epitopic part on the S-protein to neutralized the } \\
\text { SARS-CoV-2 infection }\end{array}$ \\
\hline & & 5. & $\begin{array}{l}\text { S315, S309 and S304, } \\
\text { human mAbs or Fabs }\end{array}$ & RBD of S-protein & $\begin{array}{l}\text { Bind to the RBD, without compete RBD-ACE2 binding, also neutralizing pseudotyped } \\
\text { and live SARS-CoV-2 infections }\end{array}$ \\
\hline & & 6. & SAB-185, human mAb & S-protein & Neutralized the infection of live SARS-CoV-2 \\
\hline & & 7. & LY-CoV555, human mAb & S-protein & $\begin{array}{l}\text { Stopped the viral attachment and entry into human host cells, neutralizing the } \\
\text { SARS-CoV-2 infection }\end{array}$ \\
\hline & & 8. & $\begin{array}{l}\text { n3088 and n3130, } \\
\text { human mAb }\end{array}$ & RBD of S-protein & Reduced the infections of live SARS-CoV-2 and pseudotyped \\
\hline & & 9. & $\begin{array}{l}\text { CC6.29, CC6.30 and } \\
\text { CC12.1, human mAb }\end{array}$ & RBD of S-protein & Protect from pseudotyped and live SARS-CoV-2 infections. \\
\hline & & 10. & $\begin{array}{l}4 \mathrm{~A} 8,5-24,2-17 \text { and } 4- \\
8, \text { human } \mathrm{mAb}\end{array}$ & $\begin{array}{l}\mathrm{N} \text {-terminal } \\
\text { domain of S- } \\
\text { protein }\end{array}$ & Lowered the infections of pseudotyped and live SARS-CoV-2 \\
\hline \multirow[t]{14}{*}{ Clinical } & (NCT04441918) & 11. & JS016, human mAb & S-protein & Targeting the S-protein to blocks the binding of virus into host cells by \\
\hline & (NCT04525079) & 12. & CT-P59, human mAb & RBD of S-protein & $\begin{array}{l}\text { Viral load is reduced in respiratory tracts and showing therapeutic potential for COVID- } \\
19\end{array}$ \\
\hline & (NCT04454398) & 13. & STI-1499, cocktail mAb & S-protein & Shown neutralizing activity against SARS-CoV-2 mutant variants ( spike D614G) \\
\hline & (NCT04429529) & 14. & TY027, human lgG & SARS-CoV-2 & $\begin{array}{l}\text { Its supports temporary protection from SARS-CoV-2 infection, used for treatment of } \\
\text { COVID-19 patients to slow the progression of and quicken recovery. }\end{array}$ \\
\hline & (NCT04483375) & 15. & SCTA01, human mAb & S-protein & $\begin{array}{l}\text { Competently neutralized pseudoviruses of SARS-CoV- } 2 \text { by hindering the RBD of S- } \\
\text { protein }\end{array}$ \\
\hline & (NCT04592549) & 16. & ADM03820, cocktail mAb & S-protein & $\begin{array}{l}\text { Combination of two types human IgG1 for non-competitive binding of anti-SARS-CoV- } \\
2 \text { antibodies }\end{array}$ \\
\hline & (NCT04532294) & 17. & $\begin{array}{l}\text { BGB DXP593, mAb } \\
\text { cocktails }\end{array}$ & $\begin{array}{l}\text { Ectodomain } \\
\text { trimer of S- } \\
\text { protein }\end{array}$ & Overlapping complex structure of RBD-ACE2, used to inhibits the virus entrance \\
\hline & (NCT04479631) & 18. & BRIl-196, human mAb & SARS-CoV-2 & $\begin{array}{l}\text { The epitope binding regions showed high degree of neutralizing activity against } \\
\text { SARS-CoV-2 virus }\end{array}$ \\
\hline & (NCT04561076) & 19. & HLX70, human mAb & RBD of S-protein & $\begin{array}{l}\text { Humanized mAbs targets to RBD used for the treatment of patients having COVID-19 } \\
\text { and acute respiratory disorders }\end{array}$ \\
\hline & (NCT04644120) & 20. & $\begin{array}{l}\text { ABBV-47D11, human } \\
\text { mAb }\end{array}$ & $\begin{array}{l}\text { Conserved } \\
\text { regions of S- } \\
\text { protein }\end{array}$ & $\begin{array}{l}\text { Targets the shared epitope of viruses as cross-neutralizing antibody and potential for } \\
\text { treatment of COVID-19 patients }\end{array}$ \\
\hline & (NCT04631705) & 21. & DZIF-10c, human mAb & RBD of S-protein & $\begin{array}{l}\text { Protection from virus infection within the respiratory tract injected by intravenous } \\
\text { infusion and inhalation for COVID-19 patients }\end{array}$ \\
\hline & (NCT04590430) & 22. & $\begin{array}{l}\text { HFB30132A, } \\
\text { recombinant mAb }\end{array}$ & S-protein & IgG4 having modified Fc shown minimized binding capability to human FcyRs \\
\hline & (NCT04479644) & 23. & BRIl-198, human mAb & SARS-CoV-2 & $\begin{array}{l}\text { Shown high degree of neutralizing activity of epitope binding regions in SARS-CoV-2 } \\
\text { virus. }\end{array}$ \\
\hline & (NCT04533048) & 24. & $\begin{array}{l}\text { MW33, humanized } \\
\lg \mathrm{g} 1 \kappa \mathrm{Ab}\end{array}$ & RBD of S-protein & Recombinant antibody used for COVID-19 patients having mild or moderate infection \\
\hline
\end{tabular}

Starr et al. prepared a comprehensive mutation map that is caused for the monoclonal antibody and cocktail monoclonal antibody escape. In this study, the researchers use the mAb LYCoV555 and the combination of LY-CoV016 to prepare a mutation map (211). Another group of researchers has generated 50 different mutants in the S-glycoprotein region to understand the antibody escape phenomenon. In this experiment, they have used 19 mAbs the study the neutralizing incident against the mutations. They found two significant mutations (S477N, E484K) related to the antibody escape phenomenon (212). Another experiment by Starr et al. proposed breadth of the antibody might be a significant factor that can resist the antibody escape event. The study considered important mutation locations such as E484, K417, and L45 in RBM, where frequent mutations occurred in different variants (213). Other recent studies by Greaney et al. developed a wideranging mutation map highlighting $\mathrm{RBD}$ mutations. The identified mutation sites are S309, F456, E465, E484, etc. It was noted that E484 might be mutated to any of the three amino acids such as $\mathrm{Q}, \mathrm{K}$, or $\mathrm{P}$. All these mutations may hinder the recognition and neutralization of the virus by polyclonal human plasma antibodies. However, they observed that some mutations (G485R and S494P) might trigger lesser antibodies escape phenomenon (214). However, several researchers tried to 


\section{A}

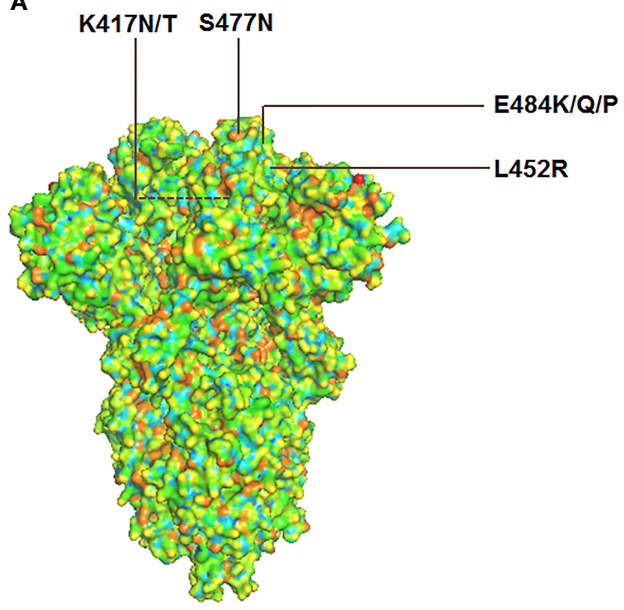

B

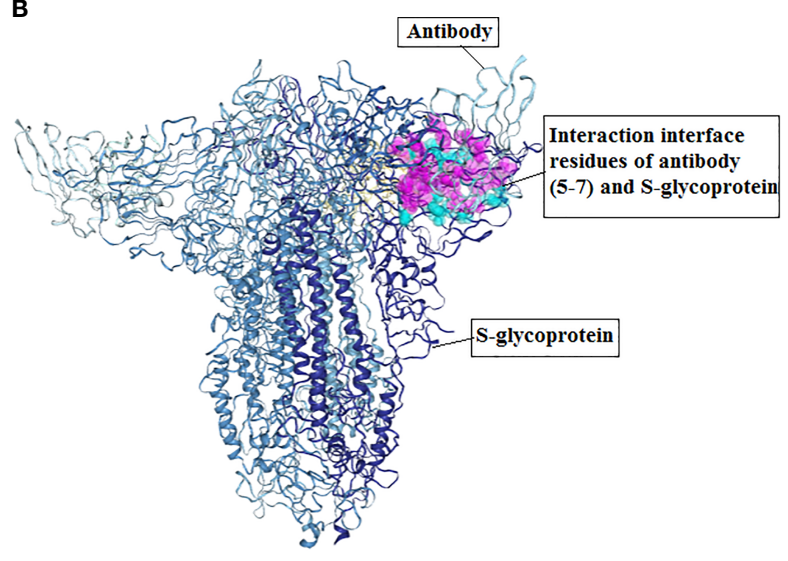

c

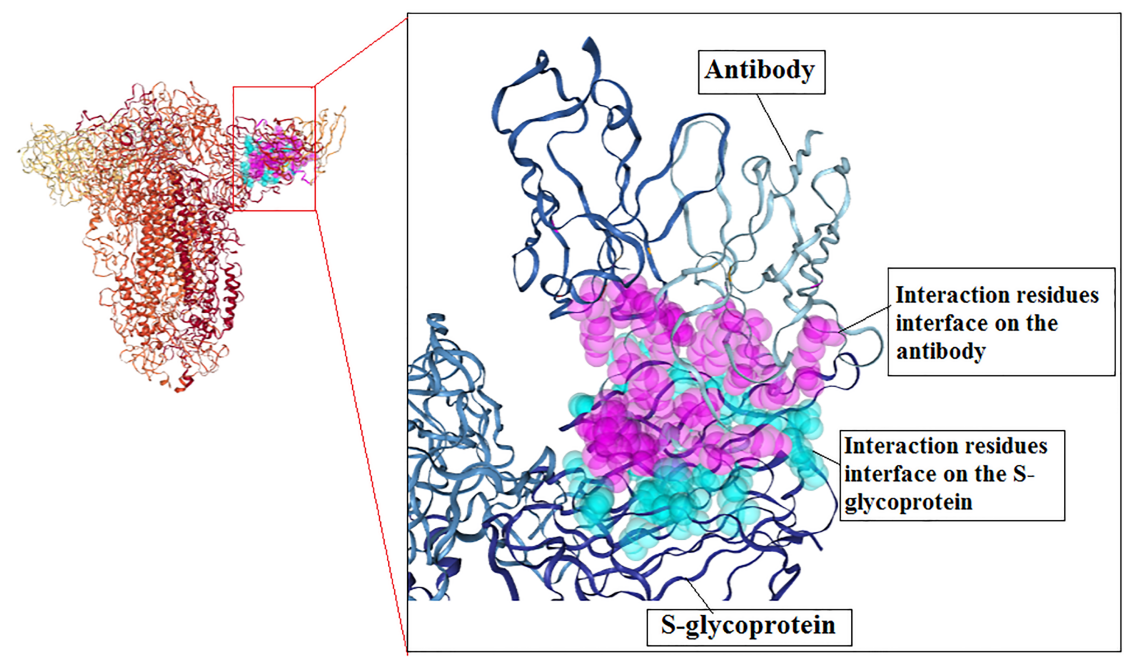

FIGURE 7 | 3D model of S-glycoprotein illustrating the location of significant mutations in the SARS-CoV-2, important variants related to antibody escape and model for antibody interaction. (A) 3D structure model shows the significant mutations for antibody escape. (B) A model for SARS-CoV-2 S-glycoprotein and antibody (5-7) interaction. The figure was generated using PDB id: 7RW2. (C) Interaction residues interface of antibody and S-glycoprotein.

describe the particular interaction sties of RBD that can interact with the specific antibodies. Simultaneously, the scientists also attempted to understand the other interaction factors and significant escape mutations that may solve the problem of the fatal virus's antibody escape property and discover the proper next-generation therapeutic antibody for the calamitous virus (215).

\subsection{Antibody Domains Against SARS-CoV-2}

Antibody domains are some naturally occurring antibodies that have a single domain. These antibodies groups are a unique class of antigen-binding fragments derived from naturally occurring antibodies. These antigen-binding fragments are also called single variable domain on a heavy chain $(\mathrm{VHH})$ and are observed in the serum of camelids $(216,217)$. Antibody domains are the smallest antigen recognizing protein domains with a $12-15 \mathrm{kDa}$ molecular weight. They are also referred as nanobodies (Nbs) $(216,217)$. These antibody domains are essential due to their therapeutic value. Single-domain antibodies have several advantages compared to monoclonal antibodies (mAbs). One of the significant differences is the smaller size of Nbs compared to conventional mAbs (about $150 \mathrm{kDa}$ ). Because of their small size, antibody domains or Nbs can access more epitopes. Simultaneously, a high amount of nanobodies (at kilogram level) can be yielded through rapid production systems such as prokaryotic expression systems. It has been reported that camelid nanobodies have revolutionized the therapy. Hence, the antibody domains are being tried to neutralize the antigenic epitopes of SARS-CoV-2. Due to the high neutralization strength, the therapeutic molecules might prevent mutational escape. Therefore, it has the possibility to neutralize a wide range of SARS-CoV-2 variants (218). Recently, Xiang et al. identified thousands of high-affinity VHH Nbs 
developed from the RBD-immunized llama serum. This study has chosen 109 immensely diverse sequences of Nbs to express in the E. coli expression system. Also, they have confirmed that 71 RBD-specific binders using an enzyme-linked immunosorbent assay (ELISA) experiment from a ninety-four purified Nbs population. Simultaneously, they found that forty-nine Nbs have a high affinity as well as high solubility. Finally, they have suggested fusing the antiviral $\mathrm{Nbs}$ in the remarkably steady albumin- $\mathrm{Nb}$ constructs, which can augment the pharmacokinetics condition (219). In another study performed by Sun et al. utilizing Antibody domains, two VH domains were selected to develop single-domain antibodies. This domain was fused to the Fc domain to augment the half-life in circulation. The two $\mathrm{VH}$ domains are $\mathrm{VH} \mathrm{m} 39$ and $\mathrm{VH}$ ab6 which can be used for the therapeutic purpose against COVID19 infection. Moreover, due to their uniqueness, these $\mathrm{VH}$ domains can be used for diagnosis (220). In the other work, Wu et al. developed a phage-displayed single-domain antibody library to develop single-domain antibodies (antibody domain) that can target five types of SARS-CoV-2 epitopes. In this study, they have grafted naive complementarity-determining regions (CDRs) into another region (framework region) of a human germline immunoglobulin heavy chain variable region (IGHV) allele. It has been noted that some of these single-domain neutralizing antibodies are able to neutralize SARS-CoV-2. Specifically, single domain neutralizing antibodies neutralize the SARS-CoV-2 Sglycoprotein trimeric interface of the cryptic form. These singledomain antibodies might act as a promising therapeutic for SARSCoV-2 and might serve as anti-SARS-CoV-2 antibodies (221). Simultaneously, Koenig et al. developed four neutralizing nanobodies, which are VHHs U, V, W, and E. These nanobodies can bind RBD of S-glycoprotein of the SARS-CoV-2. By utilizing cryo-electron microscopy and X-ray crystallography, the distinct binding abilities of these antibodies toward two epitopes was demonstrated. They showed that this modular combination of Nbs can neutralize the S-glycoprotein viral variant and thus, prevent the emergence of SARS-CoV-2 variant antibody escape (222). However, more studies are needed to understand the escape phenomena and mechanisms of single-domain antibodies against the SARS-CoV-2.

\section{CONVALESCENT PLASMA (CP) RESPONSE AND ITS ESCAPE BY THE SARS CoV-2 VARIANTS}

For the treatment of COVID-19, convalescent plasma (CP) was considered. In this direction, several studies have been performed. Duan et al. used $200 \mathrm{~mL}$ of CP derived from the donors, COVID-19 recovered individuals with nAb titers higher than 1:640 and transfused them to the COVID-19 patients. The study found potentially improved clinical outcomes (223). Volk et al. have analyzed plasma-derived IVIG/SCIG products from commercial lots to understand the neutralization capacity. The study found that around $10 \%$ of products contained above 600 $\mathrm{IU} / \mathrm{mL}$ neutralizing capacity. At the same time, they found that $50 \%$ of CP donations had low or no neutralizing power (224).
Several clinical trials have been performed to understand the efficiency of CP to patients with COVID-19 (225). Several other studies were performed to comprehend the neutralizing capacity, nAb titer level, and other factors (226). However, recent variants of SARS-CoV-2 with the new mutations have created an alarm for the neutralizing capacity of CP to treat the disease (227). We hope future studies will develop a new technology to match the $\mathrm{CP}$ characteristics based on every SARS-CoV-2 variant type and infected individuals.

\section{PARTIAL VACCINE ESCAPE}

Several COVID-19vaccines have been licensed by several countries' regulatory authorities and are rolled out for vaccination (Table 4). Recently, several studies have been performed (such as neutralization assays) to understand the vaccine efficiency related to the effect of different variants and their mutations $(228,229)$. It has been noted that the efficiency of vaccines is reducing in most cases due to the mutations in the variants (230). Vaccine escape is an interesting phenomenon, and therefore, it is urgently necessary to understand vaccine efficiency due to the emerging variants and their mutations (Figure 8). Furthermore, there is no evidence that these partial escapes resulted from vaccine-induced antibody pressure. In this direction, assays are being developed with Pseudoviruses, which are tested with sera (postvaccination). The sera are collected from the postvaccination individuals (230). Several studies have been performed to understand the impact of different vaccine effectiveness, especially using two variants (B.1.1.7 and B.1.351 variant), which indicates a reduction in vaccine effectiveness (Figure 9). We have recorded the partial vaccine escape phenomena by the different variants of the virus from time to time (Table 5), which are as follows:

\subsection{BioNTech/Pfizer mRNA Vaccine}

Recently, a pseudovirus of B.1.1.7 variants was developed in a study to understand the efficiency of the mRNA BNT162b2 vaccine. The study found a reduction of immune sera with a small amount. The study concluded that this variant might not escape the vaccine (BNT162b2) (234). Wang et al. have performed an analysis using a cohort of 20 human volunteers to understand the effect of variants on mRNA vaccine of Pfizer-BioNTech (BNT162b2) or Moderna (mRNA-1273). Here, the cohort received these mRNA vaccines. Using pseudotyped reporter virus, they constructed the virus with mutations, E484K/K417N/N501Y. The researchers observed the vaccine escape phenomenon using the pseudotype neutralization assay. They concluded that mRNA vaccines' potential loss of efficacy might need to be updated occasionally to understand the effects of variants on mRNA vaccines (235). At the same time, some studies were conducted using live viruses to understand the efficacy of mRNA vaccines. Supasa et al. found a reduction of neutralization of vaccine sera and convalescent sera against B.1.1.7 variant (about 3.3 fold reduction for these vaccines) (236). Similarly, Zhou et al. found vaccine escape from their study. They found a decrease in vaccine sera against the B.1.351 variant (about a 7.6 fold reduction for these vaccines) (237). 
TABLE 4 | Approved COVID-19 vaccines and their developers, country of origin, efficacy, and approval month.

\begin{tabular}{|c|c|c|c|c|c|}
\hline $\begin{array}{l}\text { Sl. } \\
\text { no }\end{array}$ & Vaccine name & Developer & $\begin{array}{l}\text { Country of } \\
\text { origin }\end{array}$ & Efficacy & $\begin{array}{l}\text { Month of } \\
\text { approval }\end{array}$ \\
\hline 1. & CoronaVac & Sinovac Biotech Ltd. & China & $78 \%$ & April, 2021 \\
\hline 2. & Sputnik V & Gamaleya Research Institute of Epidemiology and Microbiology & Russia & $91.6 \%$ & $\begin{array}{l}\text { December, } \\
2020\end{array}$ \\
\hline 3. & Ad5-nCoV & $\begin{array}{l}\text { Beijing Institute of Biotechnology, } \\
\text { CanSino Biologics }\end{array}$ & China & $66 \%$ & $\begin{array}{l}\text { February, } \\
2021\end{array}$ \\
\hline 4. & $\begin{array}{l}\text { Janssen COVID-19 } \\
\text { vaccine }\end{array}$ & Janssen Biotech Inc., Beth Israel Deaconess Medical Center & $\begin{array}{l}\text { United States, } \\
\text { Netherlands }\end{array}$ & $66 \%$ & $\begin{array}{l}\text { February, } \\
2021\end{array}$ \\
\hline 6. & Covivac & Russian Academy of Sciences & Russia & - & $\begin{array}{l}\text { February, } \\
2021\end{array}$ \\
\hline 7. & $\begin{array}{l}\text { Oxford-AstraZeneca, } \\
\text { COVID-19 vaccine }\end{array}$ & University of Oxford, AstraZeneca PLC & UK, Sweden & $76 \%$ & $\begin{array}{l}\text { December, } \\
2020\end{array}$ \\
\hline 8. & BBV152 (Covaxin) & Indian Council of Medical Research (ICMR), and Bharat Biotech Ltd. & India & $81 \%$ & March, 2021 \\
\hline 12. & $\begin{array}{l}\text { Moderna COVID-19 } \\
\text { vaccine }\end{array}$ & $\begin{array}{l}\text { Moderna TX, Inc., National Institute of Allergy and Infectious Diseases, Biomedical } \\
\text { Advanced Research and Development Authority, US }\end{array}$ & United States & $94 \%$ & $\begin{array}{l}\text { December, } \\
2020\end{array}$ \\
\hline 13. & WIBP-CorV & Sinopharm: Wuhan Institute of Biological Products Co., Ltd & China & $72.8 \%$ & $\begin{array}{l}\text { February, } \\
2021\end{array}$ \\
\hline 14. & QazCovid-in & Research Institute for Biological Safety Problems & Kazakhstan & - & April, 2021 \\
\hline 15. & Minhai COVID-19 vaccine & Minhai Biotechnology Co. and Kangtai Biological Products Co. Ltd & China & & May, 2021 \\
\hline
\end{tabular}
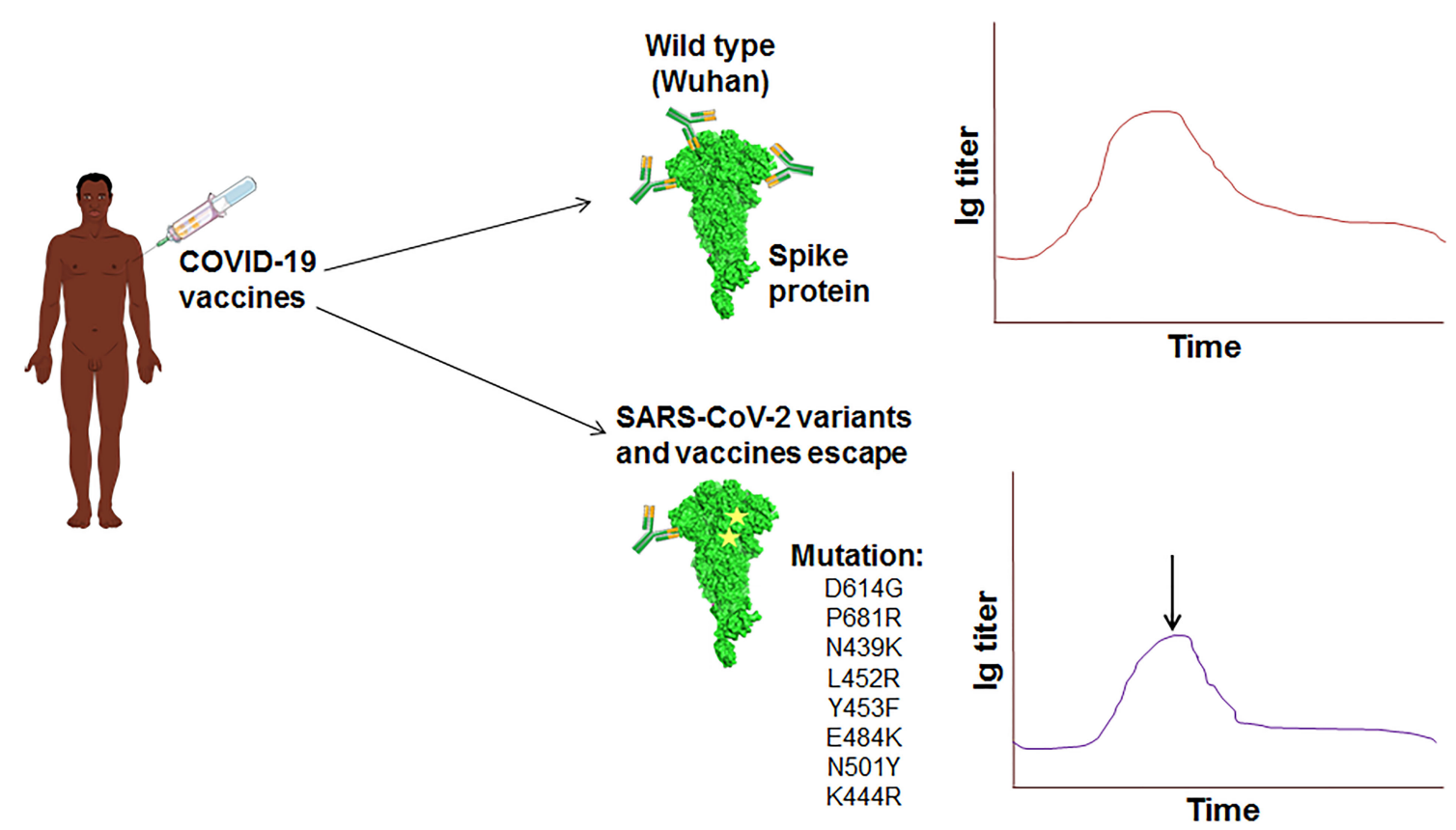

SARS-CoV-2 variants and vaccines escape

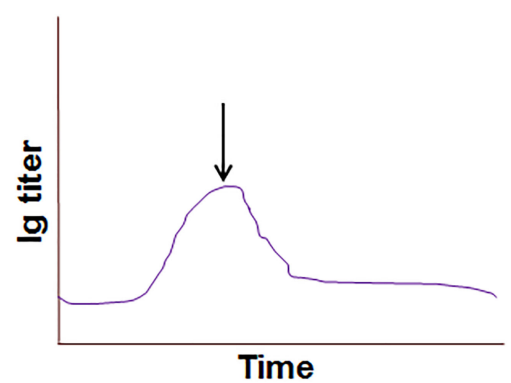

FIGURE 8 | The schematic diagram illustrates the vaccine escape and indicates the vaccine escape mutations.

\subsection{Oxford-AstraZeneca Vaccine}

It is a widely used vaccine and used by several countries like India, South Korea, etc. However, some studies found a reduction of the vaccine efficiency against the variants. Supasa et al. found a reduction of efficacy of Oxford-AstraZeneca vaccine against B.1.1.7 variant (about 3.3 fold reduction for these vaccines) (236). Similarly, Zhou et al. found a reduction of efficacy of Oxford-AstraZeneca vaccine against B.1.351 variant (about nine-fold reduction for this vaccine) (237). 


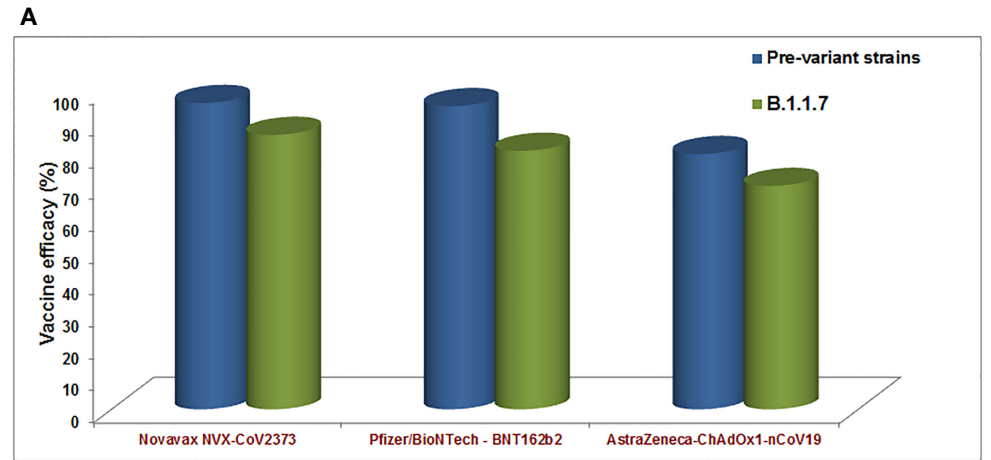

B

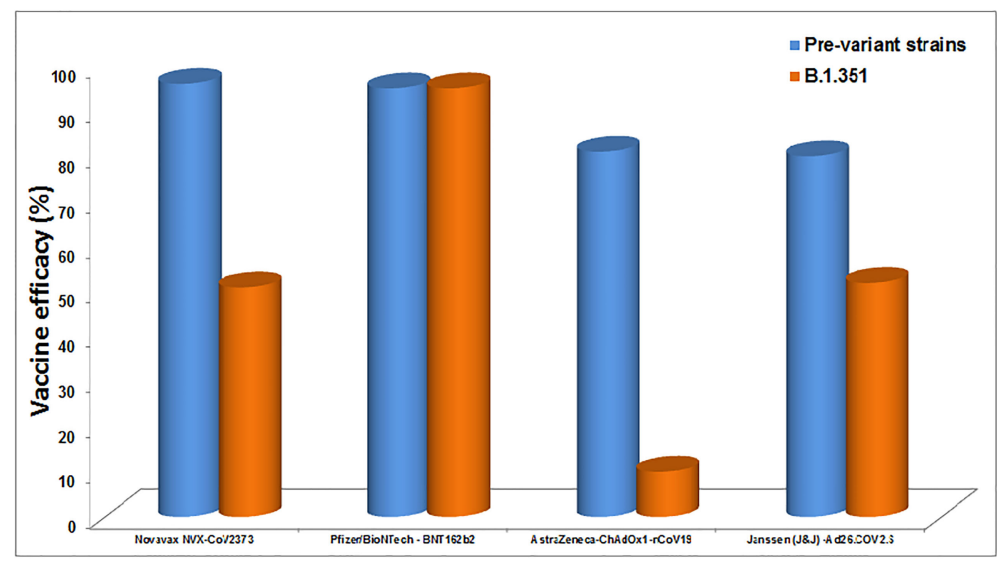

FIGURE 9 | The diagram shows the impact of different vaccines effectiveness by B.1.1.7 variants and B.1.351 variant, indicating the reduction in the vaccine effectiveness. (A) Impact of different vaccines effectiveness by B.1.1.7 variants. (B) Impact of different vaccines effectiveness by B.1.351 variant.

TABLE 5 | Vaccine efficacy against the SARS-CoV-2 significant variants.

SI. Variants

No.

Novavax NVX-CoV2373

1. B.1.1.7 The vaccine efficacy was $96 \%$ against the pre-variant strains, lowering to $86 \%$ in occurrence of B.1.1.7

2. B.1.351 Efficacy reduced from $96 \%$ to $51 \%$ 100\% operative

Efficacy reduced from 95

$\%$ to $6.7 \%$
Vaccine and efficacy

Reference

\section{Pfizer/BioNTech - AstraZeneca-ChAdOx1-} nCoV19
Efficacy was 95\%, in as $70 \%$ against B.1.1.7

Efficacy observed 10\% only
$52 \%$ efficacy observed against the moderate infection, and for severe disease (64\% South Africa) (72\% efficacy USA)
Janssen (J\&J) -Ad26.COV2.S

$(231,232)$

$-$

The data shows the reduction or neutralization of post vaccination serum and the reduction impact of vaccine effectiveness or the partial vaccine escape.

\subsection{BBIBP-CorV Vaccine and ZF2001 Vaccine}

These two vaccines are from Chinese companies and are being used in China and Uzbekistan for vaccination. Huang et al. found a reduction of vaccine efficiency against the 501Y.V2 variant for this vaccine. They found a possible reduction of 1.5 to 1.6 fold in neutralizing geometric mean titers (238).
7.4 Moderna mRNA Vaccine (mRNA-1273) and Johnson \& Johnson Vaccine (Janssen) Moderna mRNA vaccine is being widely used in several countries like the USA, Canada, Europe, and several countries in the Middle East (239-242). The neutralization efficiency of the Moderna mRNA vaccine was observed similar to the BioNTech/Pfizer 
mRNA vaccine. However, reduced efficacy was noted for the Moderna mRNA vaccine due to the different mutations in the SARS-CoV-2 variants. Wang et al. observed that variants with the mutations E484K, K417N, N501Y, and E484K in the Sglycoprotein might reduce the vaccine's efficiency. Other studies too noted the vaccine escape phenomena in the case of the Moderna mRNA vaccine (231). Finally, the scientists suggest that the mRNA vaccines may need to be restructured from time to time to end the vaccine evade phenomena (235). In another study, Garcia-Beltran et al. developed pseudoviruses with different RBD mutations or other parts of S-glycoprotein such as N501Y, $\mathrm{K} 417 \mathrm{~N} / \mathrm{T}$, and $\mathrm{E} 484 \mathrm{~K}$, to illustrate the neutralization event. They found that five out of the ten pseudoviruses with mutations are distinctly resistant to neutralization (243). Carreño et al. also found a reduction in neutralization events from low to high against different variants (244).

Similarly, several researchers noted that the different variants reduced the neutralization efficiency of the Johnson \& Johnson vaccine. Cele et al. pointed out the reduced activity by the variants, especially (501Y.V2) from country to country (57\% in South Africa and $72 \%$ in USA) (227). Therefore, scientists recommend improving vaccines from time to time, considering the mutation and variants to avoid the vaccine escape.

\section{THE STRATEGY AND INSIGHT IN VACCINE DESIGN, MABS DEVELOPMENT, AND SMALL MOLECULES (CHEMICAL COMPONENTS) BASED THERAPEUTIC DEVELOPMENT AND THEIR ESCAPE}

Most of the vaccine developed so far has considered the Sglycoprotein of Wuhan variants. Therefore, S-glycoprotein is the central point of vaccine development against SARS-CoV-2 (245). Researchers considered S-glycoprotein for vaccine development due to the highest antigenicity of the S-glycoprotein compared to other structural and non-structural proteins of SARS-CoV-2 (246). It has been noted that different types of vaccine platforms have been utilized for the vaccine development against COVID-19, such as an inactivated vaccine, subunit vaccines, nucleic acid vaccines, DNA vaccines, mRNA vaccines, recombinant vaccines, peptide and protein vaccine, VLPs (Virus-like particles), etc. (242, 247-249). Several countries approved these vaccines, and billions of people were vaccinated using them (1).

At the beginning of the pandemic, scientists have used immunoinformatics for the vaccine development for COVID-19, and several vaccine constructs were developed successfully (250254). Due to the emerging SARS-CoV-2 variants and highly mutant variants, now the antigenicity of the epitope is altering. Therefore, it is a win-win situation for both the virus and the host. In this direction, vaccine partial escape events are noteworthy by the variants (231). Scientists suggest improving the development of the next-generation vaccine for the upcoming variants. In this direction, Bhattacharya et al. proposed a vaccine construct using alternative epitopes to fight against all newly emerging SARS-CoV2 variants (255).
It has been observed that most of the antibody binds the RBD of S-glycoprotein to neutralize the antigenicity of SARS-CoV-2. Several studies have been performed to understand the interaction properties and the site between the neutralizing antibodies that bind the RBD of S-glycoprotein (256). Studies have tried to illustrate the neutralizing antibody structures and their interaction mechanism with epitopes to develop antibodybased therapeutic strategies $(129,257)$. However, several new SARS-CoV-2 variants have been generated with unique mutations in due course of time. The emerging variants of SARSCoV-2 created a concern for antibody escape events (258). The preliminary study suggests that more mutations are localized in the antibody binding regions of S-glycoprotein. Therefore, scientists are trying to develop new strategies for $\mathrm{nAb}$ development. At the same time, to prevent the antibody escape, single antibody domains may be the 'therapeutic choice' against the SARS-CoV-2 variants. A combination of antibody domains may stop the emergence of SARS-CoV-2 variant from the antibody escape (222).

Several small molecule-based therapeutics have been approved for the treatment of COVID-19. In these cases, therapeutic development strategies have mainly been used to repurpose drugs (247, 259-261). Several clinical trials have been performed from small-size to large-size depending on the number of COVID19 patients to understand the effectiveness of repurposing drugs. Some large clinical trials with most patients are ACTT-1, ACTT-2, and RECOVERY trials. These trials results showed the best therapeutic option, such as remdesivir or its combination with different antibodies (259). All the chemical components based therapeutic molecules have been developed using the drug targets, especially the primary drug target proteins of the virus or the host (262). However, the mutations in the drug target proteins were observed in the SARS-CoV-2 variants, and it is a significant concern today. One such example is remdesivir, which targets RdRp to inhibit the virus replication. Several mutations are reported in the RdRp in the newly emerging variants (258). It creates a concern for the chemical components based on therapeutic escape or therapeutic resistance.

\section{T CELL RESPONSES AGAINST SARS-CoV-2 VARIANTS}

Successful $\mathrm{T}$ cell response can halt the spread of the virus (263). It has been noted that several viral variants might evade effective immune recognition and thereby $\mathrm{T}$ cell response. Specifically, it was pointed out that the variant can escape the CD8+ T cell. It is not a common phenomenon not only for SARS-CoV-2 variants; but also for other virus variants (264). After vaccination against SARS-CoV-2, T cell-mediated immunity obstructs the virus. Some studies noted that some variants do not invade the $\mathrm{T}$ cell-mediated immunity. A recent survey by Geers et al. observed that variants like B.1.351, B.1.1.7 do not invade the $\mathrm{T}$ cellmediated immunity after BNT162b2 vaccination (265). However, after the emergence of the Omicron variant, new studies would be required to understand the $\mathrm{T}$ cell responses against the Omicron variant, as several people have contracted this variant even after being fully vaccinated. 


\section{ARRIVAL OF IMMENSELY MUTATED OMICRON VARIANT: IS IT A CONCERN FOR ANTIBODY ESCAPE AS WELL AS VACCINE ESCAPE?}

A recent SARS-CoV-2 variant was noted at the end of November 2021 called Omicron. Scientists have observed nearly 50 mutations in the genome and about 32 mutations in the Sglycoprotein of this variant $(266,267)$. Omicron has several common mutations of the Alpha variant and Delta variant. The N501Y mutation is noted in the Omicron along with other variants. This mutation augments the S-glycoprotein affinity to hACE-2 receptors, enhancing SARS-CoV-2 attachment with the host cell $(267,268)$. At the same time, E484 mutation in RBD of the S-glycoprotein has been found in the Omicron variant. This mutation is related to immune escape $(267,269)$. The Omicron variant also has a D614G mutation. The mutation helps to change the conformation of $\mathrm{RBD}$ regions and helps the fusion efficiencies with hACE-2 receptors, thus enhancing transmission and increasing the stability for the SARS-CoV-2 replication. It finally enhances infectivity (270). The D614G mutation has been reported as a positive selection (4). Simultaneously, some mutations such as R203K and G204R are too noted in the Omicron variant. These mutations augment the adaptability of the virus's evolution (267). Many other mutations have been found in the Omicron variant, such as Q493R, G496S, Q498R in $\mathrm{RBD}$ and throughout the S-glycoprotein. The role of many more mutations has not been reported so far. Thus, it is an urgent need to decipher the function of these mutations. Because of many mutations, the Omicron variant is rapidly spreading and replacing the Delta variant (271). Before two months ago, the Delta variant was the most dominating SARS-CoV-2 variant (272). At the same time, all the significant neutralizing antibodies escape phenomenon have been reported by the variant which has the capacity of evading the humoral immune response (273). Because of this, the variant is a concern for all the recent vaccines and, thereby, the vaccine effectiveness (274). Scientists are worried about the probable vaccine escape by this variant and are waiting for intensive research data. The emergence of Omicron has initiated a vaccine efficacy debate (275). Several scientists suggest booster doses of the vaccines for the fading immunity against the virus, while others favor rapid vaccine improvement to fight against the Omicron (276).

\section{LIMITATIONS}

The emergence of new SARS-CoV-2 variants has created a new direction of the pandemic. The emergence of new variants with new mutations creates a 'fresh-thinking approach' every time. After the evolution of the new SARS-CoV-2 variants, concerns regarding the vaccine escape and antibody escape event have been raised. One recent example is the identification of the Omicron variant. The quick spreading of the variant has forced scientists to consider vaccine improvement or new vaccine development for the variant. At the same time, scientists and policymakers are developing a new strategy to fight against the pandemic, for example, considering booster doses for fading immunity. Simultaneously, scientists are trying to illustrate the role of all the new mutations after the emergence of new mutations with unknown functions. It is highly desirable to know more about the new mutations and their functions in the developing variants. The review has not illustrated all these mutations due to the lack of understanding about all those new mutations.

\section{CONCLUSION}

The development of vaccines for COVID-19 is a unique success story in medical science and molecular biology, and it is an excellent example of collaboration and teamwork between researchers (277). The vaccine was rolled out within one year, and several billion vaccine doses have been administered worldwide (1). Now, emerging variants are developing throughout the globe, which is more challenging in this scenario. These variants are more prone to immune escape and partial vaccine escape. Both the escape process in light of the rising variant is enormously complex. There is clear evidence that the antigenicity changes due to the different variants, especially in the spike glycoprotein region, and the total phenomenon affects antibody neutralization. Presently it is a great challenge to understand the mechanism of immune escape and vaccine evasion. At the same time, we should appreciate the mutational process of the variants appropriately. It is also necessary to illustrate the details about the newly emerging variants generating from time to time and the efficiency of different vaccines escape against these variants. Moreover, an updated evaluation report is necessary regarding the vaccine's efficacy against the new variants. There are still many unanswered questions regarding immune escape and partial vaccine escape of the emerging variants with escape mutations. These unsolved questions need to be resolved in the shortest time possible to end the pandemic and prepare for the new pandemic.

\section{AUTHOR CONTRIBUTIONS}

CC, conceptualization, investigation, writing- original draft preparation, reviewing and editing, and supervision. AS, validation, visualization, formal analysis, reviewing, editing, and funding acquisition. MB, validation, formal analysis, visualization. S-SL, review and funding acquisition. All authors contributed to the article and approved the submitted version.

\section{FUNDING}

This study was supported by Hallym University Research Fund and by Basic Science Research Program through the National Research Foundation of Korea (NRF) funded by the Ministry of Education (NRF - 2020R1C1C1008694 and NRF- 2020R1I1A3074575). 


\section{REFERENCES}

1. Chakraborty C, Sharma AR, Bhattacharya M, Agoramoorthy G, Lee S-S. Asian-Origin Approved COVID-19 Vaccines and Current Status of COVID-19 Vaccination Program in Asia: A Critical Analysis. Vaccines (2021) 9(6):600. doi: 10.3390/vaccines 9060600

2. Chakraborty C, Sharma AR, Bhattacharya M, Agoramoorthy G, Lee S-S. All Nations Must Prioritize the COVID-19 Vaccination Program for Elderly Adults Urgently. Aging Dis (2021) 12(3):688. doi: 10.14336/AD.2021.0426

3. Chakraborty C, Bhattacharya M, Sharma AR. Present Variants of Concern and Variants of Interest of Severe Acute Respiratory Syndrome Coronavirus 2: Their Significant Mutations in S-Glycoprotein, Infectivity, Re-Infectivity, Immune Escape and Vaccines Activity. Rev Med Virol (2021) e2270. doi: $10.1002 / \mathrm{rmv} .2270$

4. Chakraborty C, Bhattacharya M, Sharma AR, Lee S-S, Agoramoorthy G. SARS-CoV-2 Brazil Variant in Latin America: More Serious Research Urgently Needed on Public Health and Vaccine Protection. Ann Med Surg (2021) 66:102428. doi: 10.1016/j.amsu.2021.102428

5. Harvey WT, Carabelli AM, Jackson B, Gupta RK, Thomson EC, Harrison EM, et al. SARS-CoV-2 Variants, Spike Mutations and Immune Escape. Nat Rev Microbiol (2021) 19(7):409-24. doi: 10.1038/s41579-021-00573-0

6. Wang H, Jean S, Eltringham R, Madison J, Snyder P, Tu H, et al. MutationSpecific SARS-CoV-2 PCR Screen: Rapid and Accurate Detection of Variants of Concern and the Identification of a Newly Emerging Variant With Spike L452R Mutation. J Clin Microbiol (2021) 59:1-8. doi: 10.1128/ JCM.00926-21. JCM. 00926-00921.

7. Guo S, Liu K, Zheng J. The Genetic Variant of SARS-CoV-2: Would It Matter for Controlling the Devastating Pandemic? Int J Biol Sci (2021) 17 (6):1476. doi: 10.7150/ijbs.59137

8. Boehm E, Kronig I, Neher RA, Eckerle I, Vetter P, Kaiser L. Novel SARSCoV-2 Variants: The Pandemics Within the Pandemic. Clin Microbiol Infect (2021) 27:1109-117. doi: 10.1016/j.cmi.2021.05.022

9. Ferraz MV, Moreira EG, Coêlho DF, Wallau GL, Lins RD. Immune Evasion of SARS-CoV-2 Variants of Concern is Driven by Low Affinity to Neutralizing Antibodies. Chem Commun (2021) 57:6094-7. doi: 10.1039/ D1CC01747K

10. Focosi D, Tuccori M, Baj A, Maggi F. SARS-CoV-2 Variants: A Synopsis of In Vitro Efficacy Data of Convalescent Plasma, Currently Marketed Vaccines, and Monoclonal Antibodies. Viruses (2021) 13(7):1211. doi: 10.3390/v13071211

11. Gupta AM, Chakrabarti J, Mandal S. Non-Synonymous Mutations of SARSCoV-2 Leads Epitope Loss and Segregates its Variants. Microbes Infection (2020) 22(10):598-607. doi: 10.1016/j.micinf.2020.10.004

12. Kim S-J, Nguyen V-G, Park Y-H, Park B-K, Chung H-C. A Novel Synonymous Mutation of SARS-CoV-2: Is This Possible to Affect Their Antigenicity and Immunogenicity? Vaccines (2020) 8(2):220. doi: 10.3390/ vaccines8020220

13. Omotuyi IO, Nash O, Ajiboye OB, Iwegbulam CG, Oyinloye EB, Oyedeji OA, et al. Atomistic Simulation Reveals Structural Mechanisms Underlying D614G Spike Glycoprotein-Enhanced Fitness in SARS-COV-2. J Comput Chem (2020) 41(24):2158-61. doi: 10.1002/jcc.26383

14. Eaaswarkhanth M, Al Madhoun A, Al-Mulla F. Could the D614G Substitution in the SARS-CoV-2 Spike (S) Protein be Associated With Higher COVID-19 Mortality? Int J Infect Dis (2020) 96:459-60. doi: 10.1016/j.ijid.2020.05.071

15. Lucas M, Karrer U, Lucas A, Klenerman P. Viral Escape MechanismsEscapology Taught by Viruses. Int J Exp Pathol (2001) 82(5):269-86. doi: 10.1046/j.1365-2613.2001.00204.x

16. Rouse BT, Sehrawat S. Immunity and Immunopathology to Viruses: What Decides the Outcome? Nat Rev Immunol (2010) 10(7):514-26. doi: 10.1038/ nri2802

17. Lauring AS, Hodcroft EB. Genetic Variants of SARS-CoV-2-What do They Mean? Jama (2021) 325(6):529-31. doi: 10.1001/jama.2020.27124

18. Atlani-Duault L, Lina B, Chauvin F, Delfraissy J-F, Malvy D. Immune Evasion Means We Need a New COVID-19 Social Contract. Lancet Public Health (2021) 6(4):e199-200. doi: 10.1016/S2468-2667(21)00036-0

19. Abdool Karim SS, de Oliveira T. New SARS-CoV-2 Variants-Clinical, Public Health, and Vaccine Implications. New Engl J Med (2021) 384 (19):1866-8. doi: 10.1056/NEJMc2100362
20. Di Caro A, Cunha F, Petrosillo N, Beeching NJ, Ergonul O, Petersen E, et al Severe Acute Respiratory Syndrome Coronavirus 2 Escape Mutants and Protective Immunity From Natural Infections or Immunizations. Clin Microbiol Infect (2021) 6:823-6. doi: 10.1016/j.cmi.2021.03.011

21. Grubaugh ND, Petrone ME, Holmes EC. We Shouldn't Worry When a Virus Mutates During Disease Outbreaks. Nat Microbiol (2020) 5(4):529-30. doi: 10.1038/s41564-020-0690-4

22. Moya A, Elena SF, Bracho A, Miralles R, Barrio E. The Evolution of RNA Viruses: A Population Genetics View. Proc Natl Acad Sci (2000) 97 (13):6967-73. doi: 10.1073/pnas.97.13.6967

23. Sanjuán R, Domingo-Calap P. Mechanisms of Viral Mutation. Cell Mol Life Sci (2016) 73(23):4433-48. doi: 10.1007/s00018-016-2299-6

24. Sanjuán R, Nebot MR, Chirico N, Mansky LM, Belshaw R. Viral Mutation Rates. J Virol (2010) 84(19):9733-48. doi: 10.1128/JVI.00694-10

25. Peck KM, Lauring AS. Complexities of Viral Mutation Rates. J Virol (2018) 92(14):e01031-01017. doi: 10.1128/JVI.01031-17

26. Loewe L, Hill WG. The Population Genetics of Mutations: Good, Bad and Indifferent. Philos Trans R Soc Lond B Biol Sci (2010) 365:1153-67. doi: 10.1098/rstb.2009.0317.

27. Duffy S. Why are RNA Virus Mutation Rates So Damn High? PloS Biol (2018) 16(8):e3000003. doi: 10.1371/journal.pbio.3000003

28. Pachetti M, Marini B, Benedetti F, Giudici F, Mauro E, Storici P, et al. Emerging SARS-CoV-2 Mutation Hot Spots Include a Novel RNADependent-RNA Polymerase Variant. J Trans Med (2020) 18(1):1-9. doi: 10.1186/s12967-020-02344-6

29. Hunt CM, McGill JM, Allen MI, Condreay LD. Clinical Relevance of Hepatitis B Viral Mutations. Hepatology (2000) 31(5):1037-44. doi: 10.1053/he.2000.6709

30. Caligiuri P, Cerruti R, Icardi G, Bruzzone B. Overview of Hepatitis B Virus Mutations and Their Implications in the Management of Infection. World J Gastroenterol (2016) 22(1):145. doi: 10.3748/wjg.v22.i1.145

31. Lee JM, Huddleston J, Doud MB, Hooper KA, Wu NC, Bedford T, et al. Deep Mutational Scanning of Hemagglutinin Helps Predict Evolutionary Fates of Human H3N2 Influenza Variants. Proc Natl Acad Sci (2018) 115 (35):E8276-85. doi: 10.1073/pnas.1806133115

32. Lyons DM, Lauring AS. Mutation and Epistasis in Influenza Virus Evolution. Viruses (2018) 10(8):407. doi: 10.3390/v10080407

33. Hie B, Zhong ED, Berger B, Bryson B. Learning the Language of Viral Evolution and Escape. Science (2021) 3716526:284-8. doi: 10.1126/science.abd7331

34. Schweighardt B, Wrin T, Meiklejohn DA, Spotts G, Petropoulos CJ, Nixon DF, et al. Immune Escape Mutations Detected Within HIV-1 Epitopes Associated With Viral Control During Treatment Interruption. J Acquir Immune Defic Syndr (2010) 53(1):36. doi: 10.1097/QAI.0b013e3181c4b885

35. Ciardi MR, Iannetta M, Zingaropoli MA, Salpini R, Aragri M, Annecca R, et al. Reactivation of Hepatitis B Virus With Immune-Escape Mutations After Ocrelizumab Treatment for Multiple Sclerosis. In: Open Forum Infectious Diseases. US: Oxford University Press (2019). ofy356.

36. Stack J, Haga IR, Schroder M, Bartlett NW, Maloney G, Reading PC, et al. Vaccinia Virus Protein A46R Targets Multiple Toll-Like-Interleukin-1 Receptor Adaptors and Contributes to Virulence. J Exp Med (2005) 201 (6):1007-18. doi: 10.1084/jem.20041442

37. Abe T, Kaname Y, Hamamoto I, Tsuda Y, Wen X, Taguwa S, et al. Hepatitis C Virus Nonstructural Protein 5A Modulates the Toll-Like ReceptorMyD88-Dependent Signaling Pathway in Macrophage Cell Lines. J Virol (2007) 81(17):8953-66. doi: 10.1128/JVI.00649-07

38. Grünvogel O, Colasanti O, Lee J-Y, Klöss V, Belouzard S, Reustle A, et al. Secretion of Hepatitis C Virus Replication Intermediates Reduces Activation of Toll-Like Receptor 3 in Hepatocytes. Gastroenterology (2018) 154 (8):2237-51.e2216. doi: 10.1053/j.gastro.2018.03.020

39. Feng Q, Langereis MA, Lork M, Nguyen M, Hato SV, Lanke K, et al. Enterovirus 2Apro Targets MDA5 and MAVS in Infected Cells. J Virol (2014) 88(6):3369-78. doi: 10.1128/JVI.02712-13

40. Lind K, Svedin E, Domsgen E, Kapell S, Laitinen OH, Moll M, et al. Coxsackievirus Counters the Host Innate Immune Response by Blocking Type III Interferon Expression. J Gen Virol (2016) 97(6):1368-80. doi: 10.1099/jgv.0.000443

41. Hatada E, Fukuda R. Binding of Influenza A Virus NS1 Protein to dsRNA In Vitro. J Gen Virol (1992) 73(12):3325-9. doi: 10.1099/0022-1317-73-12-3325 
42. Verrier ER, Yim SA, Heydmann L, El Saghire H, Bach C, Turon-Lagot V, et al. Hepatitis B Virus Evasion From Cyclic Guanosine MonophosphateAdenosine Monophosphate Synthase Sensing in Human Hepatocytes. Hepatology (2018) 68(5):1695-709. doi: 10.1002/hep.30054

43. Ramanan P, Edwards MR, Shabman RS, Leung DW, Endlich-Frazier AC, Borek DM, et al. Structural Basis for Marburg Virus VP35-mediated Immune Evasion Mechanisms. Proc Natl Acad Sci (2012) 109(50):206616. doi: 10.1073/pnas.1213559109

44. Li S-W, Wang C-Y, Jou Y-J, Huang S-H, Hsiao L-H, Wan L, et al. SARS Coronavirus Papain-Like Protease Inhibits the TLR7 Signaling Pathway Through Removing Lys63-Linked Polyubiquitination of TRAF3 and TRAF6. Int J Mol Sci (2016) 17(5):678. doi: 10.3390/ijms17050678

45. Garcia $M$, Wehbe M, Lévêque N, Bodet C. Skin Innate Immune Response to Flaviviral Infection. Eur Cytokine Netw (2017) 28(2):41-51. doi: 10.1684/ ecn.2017.0394

46. Gonzalez-Mariscal L, Garay E, Lechuga S. Virus Interaction With the Apical Junctional Complex. Front Biosci (2009) 14(2):731-68. doi: 10.2741/3276

47. Keele BF, Estes JD. Barriers to Mucosal Transmission of Immunodeficiency Viruses. Blood (2011) 118(4):839-46. doi: 10.1182/blood-2010-12-325860

48. Siu K-L, Kok K-H, Ng M-HJ, Poon VK, Yuen K-Y, Zheng B-J, et al. Severe Acute Respiratory Syndrome Coronavirus M Protein Inhibits Type I Interferon Production by Impeding the Formation of TRAF3. TANK. TBK1/IKKe Complex. J Biol Chem (2009) 284(24):16202-9. doi: 10.1074/ jbc.M109.008227

49. Ronco LV, Karpova AY, Vidal M, Howley PM. Human Papillomavirus 16 E6 Oncoprotein Binds to Interferon Regulatory Factor-3 and Inhibits its Transcriptional Activity. Genes Dev (1998) 12(13):2061-72. doi: 10.1101/ gad.12.13.2061

50. Basler CF, Mikulasova A, Martinez-Sobrido L, Paragas J, Mühlberger E, Bray M, et al. The Ebola Virus VP35 Protein Inhibits Activation of Interferon Regulatory Factor 3. J Virol (2003) 77(14):7945-56. doi: 10.1128/JVI.77.14.7945-7956.2003

51. Lei X, Xiao X, Xue Q, Jin Q, He B, Wang J. Cleavage of Interferon Regulatory Factor 7 by Enterovirus 71 3C Suppresses Cellular Responses. J Virol (2013) 87(3):1690-8. doi: 10.1128/JVI.01855-12

52. Smith GL, Benfield CT, de Motes CM, Mazzon M, Ember SW, Ferguson BJ, et al. Vaccinia Virus Immune Evasion: Mechanisms, Virulence and Immunogenicity. J Gen Virol (2013) 94(11):2367-92. doi: 10.1099/ vir.0.055921-0

53. Wang X, Li M, Zheng H, Muster T, Palese P, Beg AA, et al. Influenza A Virus NS1 Protein Prevents Activation of NF- Kb and Induction of Alpha/Beta Interferon. J Virol (2000) 74(24):11566-73. doi: 10.1128/JVI.74.24.1156611573.2000

54. Lui P-Y, Wong L-YR, Fung C-L, Siu K-L, Yeung M-L, Yuen K-S, et al. Middle East Respiratory Syndrome Coronavirus M Protein Suppresses Type I Interferon Expression Through the Inhibition of TBK1-Dependent Phosphorylation of IRF3. Emerg Microbes Infect (2016) 5(1):1-9. doi: 10.1038/emi.2016.33

55. Lee JY, Bae S, Myoung J. Middle East Respiratory Syndrome CoronavirusEncoded Accessory Proteins Impair MDA5-And TBK1-Mediated Activation of NF-kb. (2019). doi: 10.4014/jmb.1908.08004

56. Liu P, Hong Y, Yang B, Shrestha P, Sajjad N, Chen J-L. Induction of the Antiviral Immune Response and its Circumvention by Coronaviruses. Viruses (2020) 12(9):1039. doi: 10.3390/v12091039

57. Le Tortorec A, Neil SJ. Antagonism to and Intracellular Sequestration of Human Tetherin by the Human Immunodeficiency Virus Type 2 Envelope Glycoprotein. J Virol (2009) 83(22):11966-78. doi: 10.1128/JVI.01515-09

58. Thornbrough JM, Jha BK, Yount B, Goldstein SA, Li Y, Elliott R, et al. Middle East Respiratory Syndrome Coronavirus NS4b Protein Inhibits Host RNase L Activation. MBio (2016) 7(2):e00258-00216. doi: 10.1128/ mBio.00258-16

59. Short JA. Viral Evasion of Interferon Stimulated Genes. Biosci Horizons (2009) 2(2):212-24. doi: 10.1093/biohorizons/hzp014

60. Wang D, Chen J, Yu C, Zhu X, Xu S, Fang L, et al. Porcine Reproductive and Respiratory Syndrome Virus Nsp11 Antagonizes Type I Interferon Signaling by Targeting IRF9. J Virol (2019) 93(15):e00623-00619. doi: 10.1128/ JVI.00623-19

61. Sugai A, Sato H, Takayama I, Yoneda M, Kai C. Nipah and Hendra Virus Nucleoproteins Inhibit Nuclear Accumulation of Signal Transducer and
Activator of Transcription 1 (STAT1) and STAT2 by Interfering With Their Complex Formation. J Virol (2017) 91(21):e01136-01117. doi: 10.1128/ JVI.01136-17

62. Schomacker H, Hebner RM, Boonyaratanakornkit J, Surman S, AmaroCarambot E, Collins PL, et al. The C Proteins of Human Parainfluenza Virus Type 1 Block IFN Signaling by Binding and Retaining Stat1 in Perinuclear Aggregates at the Late Endosome. PloS One (2012) 7(2):e28382. doi: 10.1371/journal.pone. 0028382

63. Sen A, Rott L, Phan N, Mukherjee G, Greenberg HB. Rotavirus NSP1 Protein Inhibits Interferon-Mediated STAT1 Activation. J Virol (2014) 88(1):41-53. doi: 10.1128/JVI.01501-13

64. Ulane CM, Rodriguez JJ, Parisien J-P, Horvath CM. STAT3 Ubiquitylation and Degradation by Mumps Virus Suppress Cytokine and Oncogene Signaling. J Virol (2003) 77(11):6385-93. doi: 10.1128/JVI.77.11.63856393.2003

65. Yokota S-i, Yokosawa N, Okabayashi T, Suzutani T, Miura S, Jimbow K, et al. Induction of Suppressor of Cytokine Signaling-3 by Herpes Simplex Virus Type 1 Contributes to Inhibition of the Interferon Signaling Pathway. J Virol (2004) 78(12):6282-6. doi: 10.1128/JVI.78.12.6282-6286.2004

66. Wu Y, Liu Q, Zhou J, Xie W, Chen C, Wang Z, et al. Zika Virus Evades Interferon-Mediated Antiviral Response Through the Co-Operation of Multiple Nonstructural Proteins In Vitro. Cell Discovery (2017) 3(1):1-14. doi: 10.1038/celldisc.2017.6

67. Li S, Labrecque S, Gauzzi MC, Cuddihy AR, Wong AH, Pellegrini S, et al. The Human Papilloma Virus (HPV)-18 E6 Oncoprotein Physically Associates With Tyk2 and Impairs Jak-STAT Activation by Interferon- $\alpha$. Oncogene (1999) 18(42):5727-37. doi: 10.1038/sj.onc.1202960

68. Rosenberg W. Mechanisms of Immune Escape in Viral Hepatitis. Gut (1999) 44(5):759-64. doi: 10.1136/gut.44.5.759

69. Thimme R, Lohmann V, Weber F. A Target on the Move: Innate and Adaptive Immune Escape Strategies of Hepatitis C Virus. Antiviral Res (2006) 69(3):129-41. doi: 10.1016/j.antiviral.2005.12.001

70. Lhomme S, Migueres M, Abravanel F, Marion O, Kamar N, Izopet J. Hepatitis E Virus: How it Escapes Host Innate Immunity. Vaccines (2020) 8(3):422. doi: $10.3390 /$ vaccines 8030422

71. Vossen MT, Westerhout EM, Söderberg-Nauclér C, Wiertz EJ. Viral Immune Evasion: A Masterpiece of Evolution. Immunogenetics (2002) 54 (8):527-42. doi: 10.1007/s00251-002-0493-1

72. Wargo AR, Kurath G. Viral Fitness: Definitions, Measurement, and Current Insights. Curr Opin Virol (2012) 2(5):538-45. doi: 10.1016/j.coviro. 2012.07.007

73. Uebelhoer L, Han J-H, Callendret B, Mateu G, Shoukry NH, Hanson HL, et al. Stable Cytotoxic T Cell Escape Mutation in Hepatitis C Virus is Linked to Maintenance of Viral Fitness. PloS Pathog (2008) 4(9):e1000143. doi: 10.1371/journal.ppat.1000143

74. Song H, Pavlicek JW, Cai F, Bhattacharya T, Li H, Iyer SS, et al. Impact of Immune Escape Mutations on HIV-1 Fitness in the Context of the Cognate Transmitted/Founder Genome. Retrovirology (2012) 9(1):1-14. doi: $10.1186 / 1742-4690-9-89$

75. Majumdar P, Niyogi S. SARS-CoV-2 Mutations: The Biological Trackway Towards Viral Fitness. Epidemiol Infect (2021) 149. doi: 10.1017/ S0950268821001060

76. Sochocka M. Rozpoznawanie Patogenów Przez Wrodzony System Odporności Recognition of Pathogens by Innate Immunity. Postepy Hig Med Dosw (2008) 62:676-87.

77. Takeuchi O, Akira S. Innate Immunity to Virus Infection. Immunol Rev (2009) 227(1):75-86. doi: 10.1111/j.1600-065X.2008.00737.x

78. Gasteiger G, D'osualdo A, Schubert DA, Weber A, Bruscia EM, Hartl D. Cellular Innate Immunity: An Old Game With New Players. J Innate Immun (2017) 9(2):111-25. doi: 10.1159/000453397

79. Sanders CJ, Doherty PC, Thomas PG. Respiratory Epithelial Cells in Innate Immunity to Influenza Virus Infection. Cell Tissue Res (2011) 343(1):13-21. doi: 10.1007/s00441-010-1043-z

80. Rai KR, Shrestha P, Yang B, Chen Y, Liu S, Maarouf M, et al. Acute Infection of Viral Pathogens and Their Innate Immune Escape. Front Microbiol (2021) 121358. doi: $10.3389 /$ fmicb. 2021.672026

81. Martin TR, Frevert CW. Innate Immunity in the Lungs. Proc Am Thorac Soc (2005) 2(5):403-11. doi: 10.1513/pats.200508-090JS 
82. Akira S, Uematsu S, Takeuchi O. Pathogen Recognition and Innate Immunity. Cell (2006) 124(4):783-801. doi: 10.1016/j.cell.2006.02.015

83. Medzhitov R. Recognition of Microorganisms and Activation of the Immune Response. Nature (2007) 449(7164):819-26. doi: 10.1038/nature06246

84. Kawai T, Akira S. The Roles of TLRs, RLRs and NLRs in Pathogen Recognition. Int Immunol (2009) 21(4):317-37. doi: 10.1093/intimm/ dxp017

85. Blanco-Melo D, Nilsson-Payant BE, Liu W-C, Uhl S, Hoagland D, Møller R, et al. Imbalanced Host Response to SARS-CoV-2 Drives Development of COVID-19. Cell (2020) 181(5):1036-45.e1039. doi: 10.1016/j.cell. 2020.04 .026

86. Stanifer ML, Kee C, Cortese M, Zumaran CM, Triana S, Mukenhirn M, et al. Critical Role of Type III Interferon in Controlling SARS-CoV-2 Infection in Human Intestinal Epithelial Cells. Cell Rep (2020) 32(1):107863. doi: 10.1016/j.celrep.2020.107863

87. Lei X, Dong X, Ma R, Wang W, Xiao X, Tian Z, et al. Activation and Evasion of Type I Interferon Responses by SARS-CoV-2. Nat Commun (2020) 11 (1):1-12. doi: 10.1038/s41467-020-17665-9

88. Rebendenne A, Chaves Valadão AL, Tauziet M, Maarifi G, Bonaventure B, McKellar J, et al. SARS-CoV-2 Triggers an MDA-5-Dependent Interferon Response Which is Unable to Control Replication in Lung Epithelial Cells. J Virol (2021) 95(8):e02415-20. doi: 10.1128/JVI.02415-20

89. Miorin L, Kehrer T, Sanchez-Aparicio MT, Zhang K, Cohen P, Patel RS, et al. SARS-CoV-2 Orf6 Hijacks Nup98 to Block STAT Nuclear Import and Antagonize Interferon Signaling. Proc Natl Acad Sci (2020) 117(45):2834454. doi: 10.1073/pnas.2016650117

90. Sa Ribero M, Jouvenet N, Dreux M, Nisole S. Interplay Between SARS-CoV2 and the Type I Interferon Response. PloS Pathog (2020) 16(7):e1008737. doi: 10.1371/journal.ppat.1008737

91. Agrawal A. Mechanisms and Implications of Age-Associated Impaired Innate Interferon Secretion by Dendritic Cells: A Mini-Review. Gerontology (2013) 59(5):421-6. doi: 10.1159/000350536

92. King C, Sprent J. The Dual Nature of Type-I Interferons in SARS-CoV-2 Induced Inflammation. Trends Immunol (2021) 42(4):312-22. doi: 10.1016/ j.it.2021.02.003

93. Lokugamage KG, Hage A, de Vries M, Valero-Jimenez AM, Schindewolf C, Dittmann M, et al. Type I Interferon Susceptibility Distinguishes SARSCoV-2 From SARS-CoV. J Virol (2020) 94(23):e01410-20. doi: 10.1128/ JVI.01410-20

94. Mantlo E, Bukreyeva N, Maruyama J, Paessler S, Huang C. Antiviral Activities of Type I Interferons to SARS-CoV-2 Infection. Antiviral Res (2020) 179:104811. doi: 10.1016/j.antiviral.2020.104811

95. Xia H, Shi P-Y. Antagonism of Type I Interferon by Severe Acute Respiratory Syndrome Coronavirus 2. J Interferon Cytokine Res (2020) 40 (12):543-8. doi: 10.1089/jir.2020.0214

96. Ruan Q, Yang K, Wang W, Jiang L, Song J. Clinical Predictors of Mortality Due to COVID-19 Based on an Analysis of Data of 150 Patients From Wuhan, China. Intensive Care Med (2020) 46(5):846-8. doi: 10.1007/ s00134-020-05991-x

97. Zhang J, Hao Y, Ou W, Ming F, Liang G, Qian Y, et al. Serum Interleukin-6 is an Indicator for Severity in 901 Patients With SARS-CoV-2 Infection: A Cohort Study. J Trans Med (2020) 18(1):1-8. doi: 10.1186/s12967-02002571-x

98. Bhattacharya M, Sharma AR, Mallick B, Sharma G, Lee S-S, Chakraborty C. Immunoinformatics Approach to Understand Molecular Interaction Between Multi-Epitopic Regions of SARS-CoV-2 Spike-Protein With TLR4/MD-2 Complex. Infect Genet Evol (2020) 85:104587. doi: 10.1016/ j.meegid.2020.104587

99. Chakraborty C, Sharma AR, Bhattacharya M, Sharma G, Lee SS, Agoramoorthy G. COVID-19: Consider IL-6 Receptor Antagonist for the Therapy of Cytokine Storm Syndrome in SARS-CoV-2 Infected Patients. J Med Virol (2020) 92(11):2260-2. doi: 10.1002/jmv.26078

100. Khanmohammadi S, Rezaei N. Role of Toll-Like Receptors in the Pathogenesis of COVID-19. J Med Virol (2021) 93(5):2735-9. doi: 10.1002/jmv. 26826

101. Chen G, Wu D, Guo W, Cao Y, Huang D, Wang H, et al. Clinical and Immunological Features of Severe and Moderate Coronavirus Disease 2019. J Clin Invest (2020) 130(5):2620-9. doi: 10.1172/JCI137244
102. Costela-Ruiz VJ, Illescas-Montes R, Puerta-Puerta JM, Ruiz C, MelguizoRodríguez L. SARS-CoV-2 Infection: The Role of Cytokines in COVID-19 Disease. Cytokine Growth Factor Rev (2020) 54:62-75. doi: 10.1016/ j.cytogfr.2020.06.001

103. Liu Y, Yan L-M, Wan L, Xiang T-X, Le A, Liu J-M, et al. Viral Dynamics in Mild and Severe Cases of COVID-19. Lancet Infect Dis (2020) 20(6):656-7. doi: 10.1016/S1473-3099(20)30232-2

104. Blanco P, Palucka AK, Pascual V, Banchereau J. Dendritic Cells and Cytokines in Human Inflammatory and Autoimmune Diseases. Cytokine Growth Factor Rev (2008) 19(1):41-52. doi: 10.1016/j.cytogfr.2007.10.004

105. Rao VU, Arakeri G, Subash A, Rao J, Jadhav S, Sayeed MS, et al. COVID-19: Loss of Bridging Between Innate and Adaptive Immunity? Med Hypotheses (2020) 144:109861. doi: 10.1016/j.mehy.2020.109861

106. Schaefer BC, Schaefer ML, Kappler JW, Marrack P, Kedl RM. Observation of Antigen-Dependent CD8+ T-Cell/Dendritic Cell Interactions In Vivo. Cell Immunol (2001) 214(2):110-22. doi: 10.1006/cimm.2001.1895

107. Sallusto F, Lanzavecchia A. The Instructive Role of Dendritic Cells on T-Cell Responses. Arthritis Res Ther (2002) 4(3):1-6. doi: 10.1186/ar567

108. Mount AM, Smith CM, Kupresanin F, Stoermer K, Heath WR, Belz GT. Multiple Dendritic Cell Populations Activate CD4+ T Cells After Viral Stimulation. PloS One (2008) 3(2):e1691. doi: 10.1371/journal.pone.0001691

109. Swain SL, McKinstry KK, Strutt TM. Expanding Roles for CD4+ T Cells in Immunity to Viruses. Nat Rev Immunol (2012) 12(2):136-48. doi: 10.1038/ nri3152

110. Zhou R, To KK-W, Wong Y-C, Liu L, Zhou B, Li X, et al. Acute SARS-CoV-2 Infection Impairs Dendritic Cell and T Cell Responses. Immunity (2020) 53 (4):864-77.e865. doi: 10.1016/j.immuni.2020.07.026

111. Brufsky A, Marti JLG, Nasrazadani A, Lotze MT. Boning Up: AminoBisphophonates as Immunostimulants and Endosomal Disruptors of Dendritic Cell in SARS-CoV-2 Infection. J Trans Med (2020) 18(1):1-6. doi: 10.1186/s12967-020-02433-6

112. Zhang Z, Wang F, Zhao M, Liu J, Xu D, Jin L, et al. Characterization of Peripheral Dendritic Cell Subsets and its Implication in Patients Infected With Severe Acute Respiratory Syndrome. Zhonghua Yi Xue Za Zhi (2004) 84(1):22-6.

113. Liu L, Wei Q, Lin Q, Fang J, Wang H, Kwok H, et al. Anti-spike IgG Causes Severe Acute Lung Injury by Skewing Macrophage Responses During Acute SARS-CoV Infection. JCI Insight (2019) 4(4):e123158. doi: 10.1172/ jci.insight. 123158

114. Channappanavar R, Fehr AR, Vijay R, Mack M, Zhao J, Meyerholz DK, et al. Dysregulated Type I Interferon and Inflammatory Monocyte-Macrophage Responses Cause Lethal Pneumonia in SARS-CoV-Infected Mice. Cell Host Microbe (2016) 19(2):181-93. doi: 10.1016/j.chom.2016.01.007

115. Jafarzadeh A, Chauhan P, Saha B, Jafarzadeh S, Nemati M. Contribution of Monocytes and Macrophages to the Local Tissue Inflammation and Cytokine Storm in COVID-19: Lessons From SARS and MERS, and Potential Therapeutic Interventions. Life Sci (2020) 257:118102. doi: 10.1016/j.lfs.2020.118102

116. Liao M, Liu Y, Yuan J, Wen Y, Xu G, Zhao J, et al. Single-Cell Landscape of Bronchoalveolar Immune Cells in Patients With COVID-19. Nat Med (2020) 26(6):842-4. doi: 10.1038/s41591-020-0901-9

117. Abassi Z, Knaney Y, Karram T, Heyman SN. The Lung Macrophage in SARS-CoV-2 Infection: A Friend or a Foe? Front Immunol (2020) 11:1312. doi: $10.3389 /$ fimmu.2020.01312

118. Taefehshokr N, Taefehshokr S, Hemmat N, Heit B. Covid-19: Perspectives on Innate Immune Evasion. Front Immunol (2020) 11. doi: 10.3389/ fimmu.2020.580641

119. Dalskov L, Møhlenberg M, Thyrsted J, Blay-Cadanet J, Poulsen ET, Folkersen $\mathrm{BH}$, et al. SARS-CoV-2 Evades Immune Detection in Alveolar Macrophages. EMBO Rep (2020) 21(12):e51252. doi: 10.15252/embr.202051252

120. Lv J, Wang Z, Qu Y, Zhu H, Zhu Q, Tong W, et al. Distinct Uptake, Amplification, and Release of SARS-CoV-2 by M1 and M2 Alveolar Macrophages. Cell Discov (2021) 7(1):1-12. doi: 10.1038/s41421-021-00258-1

121. Vivier E, Tomasello E, Baratin M, Walzer T, Ugolini S. Functions of Natural Killer Cells. Nat Immunol (2008) 9(5):503-10. doi: 10.1038/ni1582

122. van Erp EA, van Kampen MR, van Kasteren PB, de Wit J. Viral Infection of Human Natural Killer Cells. Viruses (2019) 11(3):243. doi: 10.3390/ v11030243 
123. Mancini M, Vidal SM. Mechanisms of Natural Killer Cell Evasion Through Viral Adaptation. Annu Rev Immunol (2020) 38:511-39. doi: 10.1146/ annurev-immunol-082619-124440

124. Zheng M, Gao Y, Wang G, Song G, Liu S, Sun D, et al. Functional Exhaustion of Antiviral Lymphocytes in COVID-19 Patients. Cell Mol Immunol (2020) 17(5):533-5. doi: 10.1038/s41423-020-0402-2

125. Wang F, Hou H, Luo Y, Tang G, Wu S, Huang M, et al. The Laboratory Tests and Host Immunity of COVID-19 Patients With Different Severity of Illness. JCI Insight (2020) 5(10):e137799. doi: 10.1172/jci.insight.137799

126. Wang F, Nie J, Wang H, Zhao Q, Xiong Y, Deng L, et al. Characteristics of Peripheral Lymphocyte Subset Alteration in COVID-19 Pneumonia. J Infect Dis (2020) 221(11):1762-9. doi: 10.1093/infdis/jiaa150

127. Littera R, Chessa L, Deidda S, Angioni G, Campagna M, Lai S, et al. Natural Killer-Cell Immunoglobulin-Like Receptors Trigger Differences in Immune Response to SARS-CoV-2 Infection. PloS One (2021) 16(8):e0255608. doi: 10.1371/journal.pone. 0255608

128. Camp JV, Jonsson CB. A Role for Neutrophils in Viral Respiratory Disease. Front Immunol (2017) 8:550. doi: 10.3389/fimmu.2017.00550

129. Barnes BJ, Adrover JM, Baxter-Stoltzfus A, Borczuk A, Cools-Lartigue J, Crawford JM, et al. Targeting Potential Drivers of COVID-19: Neutrophil Extracellular Traps. J Exp Med (2020) 217(6):e20200652. doi: 10.1084/ jem. 20200652

130. Zuo Y, Yalavarthi S, Shi H, Gockman K, Zuo M, Madison J, et al. Neutrophil Extracellular Traps in COVID-19. JCI Insight (2020) 5(11):e138999. doi: 10.1172/jci.insight.138999.

131. Rosa BA, Ahmed M, Singh DK, Choreño-Parra JA, Cole J, Jiménez-Álvarez LA, et al. IFN Signaling and Neutrophil Degranulation Transcriptional Signatures are Induced During SARS-CoV-2 Infection. Commun Biol (2021) 4(1):1-14. doi: 10.1038/s42003-021-01829-4

132. Xiong Y, Liu Y, Cao L, Wang D, Guo M, Jiang A, et al. Transcriptomic Characteristics of Bronchoalveolar Lavage Fluid and Peripheral Blood Mononuclear Cells in COVID-19 Patients. Emerg Microbes Infection (2020) 9(1):761-70. doi: 10.1080/22221751.2020.1747363

133. Qin C, Zhou L, Hu Z, Zhang S, Yang S, Tao Y, et al. Dysregulation of Immune Response in Patients With COVID-19 in Wuhan. China (February 17 2020) (2020) 71:762-8. doi: 10.1093/cid/ciaa248

134. Guan W-J, Ni Z-Y, Hu Y, Liang W-H, Ou C-Q, He J-X, et al. China Medical Treatment Expert Group for Covid-19. Clin Charact Coronavirus Dis (2019) 382:1708-20. doi: 10.1056/NEJMoa2002032

135. Tay MZ, Poh CM, Rénia L, MacAry PA, Ng LF. The Trinity of COVID-19: Immunity, Inflammation and Intervention. Nat Rev Immunol (2020) 20 (6):363-74. doi: 10.1038/s41577-020-0311-8

136. Kumar P, Sobhanan J, Takano Y, Biju V. Molecular Recognition in the Infection, Replication, and Transmission of COVID-19-Causing SARS-CoV2: An Emerging Interface of Infectious Disease, Biological Chemistry, and Nanoscience. NPG Asia Mater (2021) 13(1):1-14. doi: 10.1038/s41427-02000275-8

137. Bickler SW, Cauvi DM, Fisch KM, Prieto JM, Sykes AG, Thangarajah H, et al. Extremes of Age are Associated With Differences in the Expression of Selected Pattern Recognition Receptor Genes and ACE2, the Receptor for SARS-CoV-2: Implications for the Epidemiology of COVID-19 Disease. BMC Med Genomics (2021) 14(1):1-8. doi: 10.1186/s12920-021-00970-7

138. Chakraborty C, Sharma AR, Bhattacharya M, Sharma G, Lee SS, Agoramoorthy G. Consider TLR5 for New Therapeutic Development Against COVID-19. J Med Virol (2020) doi:2314-5. doi: 10.1002/jmv.25997

139. Mba IE, Sharndama HC, Osondu-Chuka GO, Okeke OP. Immunobiology and Nanotherapeutics of Severe Acute Respiratory Syndrome 2 (SARS-CoV2): A Current Update. Infect Dis (2021) 53(8):559-80. doi: 10.1080/ 23744235.2021.1916071

140. Zhao Y, Kuang M, Li J, Zhu L, Jia Z, Guo X, et al. SARS-CoV-2 Spike Protein Interacts With and Activates TLR41. Cell Res (2021) 31:1-3. doi: 10.1038/ s41422-021-00495-9

141. Schroder K, Tschopp J. The Inflammasomes. Cell (2010) 140(6):821-32. doi: 10.1016/j.cell.2010.01.040

142. Lee G-S, Subramanian N, Kim AI, Aksentijevich I, Goldbach-Mansky R, Sacks DB, et al. The Calcium-Sensing Receptor Regulates the NLRP3 Inflammasome Through Ca 2+ and cAMP. Nature (2012) 492(7427):1237. doi: $10.1038 /$ nature 11588
143. Kelley N, Jeltema D, Duan Y, He Y. The NLRP3 Inflammasome: An Overview of Mechanisms of Activation and Regulation. Int J Mol Sci (2019) 20(13):3328. doi: 10.3390/ijms20133328

144. Siu KL, Yuen KS, Castano-Rodriguez C, Ye ZW, Yeung ML, Fung SY, et al. Severe Acute Respiratory Syndrome Coronavirus ORF3a Protein Activates the NLRP3 Inflammasome by Promoting TRAF3-Dependent Ubiquitination of ASC. FASEB J (2019) 33(8):8865-77. doi: 10.1096/fj.201802418R

145. Issa E, Merhi G, Panossian B, Salloum T, Tokajian S. SARS-CoV-2 and ORF3a: Nonsynonymous Mutations, Functional Domains, and Viral Pathogenesis. Msystems (2020) 5(3):e00266-00220. doi: 10.1128/ mSystems.00266-20

146. Bouayad A. Innate Immune Evasion by SARS-CoV-2: Comparison With SARS-CoV. Rev Med Virol (2020) 30(6):1-9. doi: 10.1002/rmv.2135

147. de Rivero Vaccari JC, Dietrich WD, Keane RW, de Rivero Vaccari JP. The Inflammasome in Times of COVID-19. Front Immunol (2020) 11:2474. doi: 10.3389/fimmu.2020.583373

148. Zheng M, Williams EP, Malireddi RS, Karki R, Banoth B, Burton A, et al. Impaired NLRP3 Inflammasome Activation/Pyroptosis Leads to Robust Inflammatory Cell Death via Caspase-8/RIPK3 During Coronavirus Infection. J Biol Chem (2020) 295(41):14040-52. doi: 10.1074/jbc.RA120.015036

149. Lara PC, Macías-Verde D, Burgos-Burgos J. Age-Induced NLRP3 Inflammasome Over-Activation Increases Lethality of SARS-CoV-2 Pneumonia in Elderly Patients. Aging Dis (2020) 11(4):756. doi: 10.14336/ AD.2020.0601

150. Kim N-E, Kim D-K, Song Y-J. SARS-CoV-2 Nonstructural Proteins 1 and 13 Suppress Caspase-1 and the NLRP3 Inflammasome Activation. Microorganisms (2021) 9(3):494. doi: 10.3390/microorganisms9030494

151. Duchene S, Featherstone L, Haritopoulou-Sinanidou M, Rambaut A, Lemey P, Baele G. Temporal Signal and the Phylodynamic Threshold of SARS-CoV2. Virus Evol (2020) 6(2):veaa061. doi: 10.1093/ve/veaa061

152. Worobey M, Pekar J, Larsen BB, Nelson MI, Hill V, Joy JB, et al. The Emergence of Sars-Cov-2 in Europe and North America. Science (2020) 370 (6516):564-70. doi: 10.1126/science.abc8169

153. Chakraborty C, Sharma AR, Bhattacharya M, Agoramoorthy G, Lee SS. Newly Emerging SARS-CoV-2 Variants, Evolution, Their Mode of Transmission and Mutational Landscape. mBio (2021) 12(4):e0114021. doi: 10.1128/mBio.01140-21

154. Korber B, Fischer WM, Gnanakaran S, Yoon H, Theiler J, Abfalterer W, et al. Tracking Changes in SARS-CoV-2 Spike: Evidence That D614G Increases Infectivity of the COVID-19 Virus. Cell (2020) 182(4):812-27.e819. doi: 10.1016/j.cell.2020.06.043

155. Mansbach RA, Chakraborty S, Nguyen K, Montefiori DC, Korber B, Gnanakaran S. The SARS-CoV-2 Spike Variant D614G Favors an Open Conformational State. Sci Adv (2021) 7(16):eabf3671. doi: 10.1126/ sciadv.abf3671

156. Cherian S, Potdar V, Jadhav S, Yadav P, Gupta N, Das M, et al. SARS-CoV-2 Spike Mutations, L452R, T478K, E484Q and P681R, in the Second Wave of COVID-19 in Maharashtra, India. Microorganisms (2021) 1542 9(7):1-11. doi: 10.3390/microorganisms 9071542

157. Pascarella S, Ciccozzi M, Zella D, Bianchi M, Benedetti F, Broccolo F, et al. SARS-CoV-2 B. 1.617 Indian Variants: Are Electrostatic Potential Changes Responsible for a Higher Transmission Rate? J Med Virol (2021) 93:6551-6. doi: $10.1002 / j m v .27210$

158. Zhou W, Xu C, Wang P, Luo M, Xu Z, Cheng R, et al. N439K Variant in Spike Protein Alter the Infection Efficiency and Antigenicity of SARS-CoV-2 Based on Molecular Dynamics Simulation. Front Cell Dev Biol (2021) 9:2071. doi: 10.1101/2020.11.21.392407

159. Deng X, Garcia-Knight MA, Khalid MM, Servellita V, Wang C, Morris MK, et al. Transmission, Infectivity, and Neutralization of a Spike L452R SARSCoV-2 Variant. Cell (2021) 184:3426-37. doi: 10.1016/j.cell.2021.04.025. 03.07.21252647.

160. Starr TN, Greaney AJ, Hilton SK, Ellis D, Crawford KH, Dingens AS, et al. Deep Mutational Scanning of SARS-CoV-2 Receptor Binding Domain Reveals Constraints on Folding and ACE2 Binding. Cell (2020) 182 (5):1295-310.e1220. doi: 10.1016/j.cell.2020.08.012

161. Jangra S, Ye C, Rathnasinghe R, Stadlbauer D, Alshammary H, Amoako AA, et al. SARS-CoV-2 Spike E484K Mutation Reduces Antibody Neutralisation. Lancet Microbe (2021) 2(7):e283-4. doi: 10.1016/S2666-5247(21)00068-9 
162. Niu Z, Zhang Z, Gao X, Du P, Lu J, Yan B, et al. N501Y Mutation Imparts Cross-Species Transmission of SARS-CoV-2 to Mice by Enhancing Receptor Binding. Signal Transduct Target Ther (2021) 6(1):1-3. doi: 10.1038/s41392021-00704-2

163. Tian F, Tong B, Sun L, Shi S, Zheng B, Wang Z, et al. N501Y Mutation of Spike Protein in SARS-CoV-2 Strengthens its Binding to Receptor ACE2. Elife (2021) 10:e69091. doi: 10.7554/eLife.69091

164. Ortega JT, Pujol FH, Jastrzebska B, Rangel HR. Mutations in the SARS-CoV-2 Spike Protein Modulate the Virus Affinity to the Human ACE2 Receptor, an in Silico Analysis. EXCLI J (2021) 20:585. doi: 10.3390/pathogens11010045

165. Benedetti F, Snyder GA, Giovanetti M, Angeletti S, Gallo RC, Ciccozzi M, et al. Emerging of a SARS-CoV-2 Viral Strain With a Deletion in Nsp1. J Trans Med (2020) 18(1):1-6. doi: 10.1186/s12967-020-02507-5

166. Weisblum Y, Schmidt F, Zhang F, DaSilva J, Poston D, Lorenzi JC, et al. Escape From Neutralizing Antibodies by SARS-CoV-2 Spike Protein Variants. Elife (2020) 9:e61312. doi: 10.7554/eLife.61312

167. Banoun H. Evolution of SARS-CoV-2: Review of Mutations, Role of the Host Immune System. Nephron (2021)145:1-12. doi: 10.1159/000515417

168. Wang R, Chen J, Hozumi Y, Yin C, Wei G-W. Decoding Asymptomatic COVID-19 Infection and Transmission. J Phys Chem Lett (2020) 11 (23):10007-15. doi: 10.1021/acs.jpclett.0c02765

169. Bianchi M, Borsetti A, Ciccozzi M, Pascarella S. SARS-Cov-2 ORF3a: Mutability and Function. Int J Biol Macromol (2021) 170:820-6. doi: 10.1016/j.ijbiomac.2020.12.142

170. Young BE, Fong S-W, Chan Y-H, Mak T-M, Ang LW, Anderson DE, et al. Effects of a Major Deletion in the SARS-CoV-2 Genome on the Severity of Infection and the Inflammatory Response: An Observational Cohort Study. Lancet (2020) 396(10251):603-11. doi: 10.1016/S01406736(20)31757-8

171. Koyama T, Weeraratne D, Snowdon JL, Parida L. Emergence of Drift Variants That may Affect COVID-19 Vaccine Development and Antibody Treatment. Pathogens (2020) 9(5):324. doi: 10.3390/pathogens9050324

172. Spielman SJ, Wilke CO. The Relationship Between Dn/dS and Scaled Selection Coefficients. Mol Biol Evol (2015) 32(4):1097-108. doi: 10.1093/ molbev/msv003

173. Berrio A, Gartner V, Wray GA. Positive Selection Within the Genomes of SARS-CoV-2 and Other Coronaviruses Independent of Impact on Protein Function. PeerJ (2020) 8:e10234. doi: 10.7717/peerj.10234

174. Chakraborty C, Saha A, AR S, Bhattacharya M, SS L, Agoramoorthy G. D614G Mutation Eventuates in All VOI and VOC in SARS-CoV-2: Is it Part of the Positive Selection Pioneered by Darwin? Mol Ther-Nucl Acids (2021) 26:237-41. doi: 10.1016/j.omtn.2021.07.011

175. Li Q, Wu J, Nie J, Zhang L, Hao H, Liu S, et al. The Impact of Mutations in SARS-CoV-2 Spike on Viral Infectivity and Antigenicity. Cell (2020) 182 (5):1284-94.e1289. doi: 10.1016/j.cell.2020.07.012

176. Ozono S, Zhang Y, Ode H, Sano K, Tan TS, Imai K, et al. SARS-CoV-2 D614G Spike Mutation Increases Entry Efficiency With Enhanced ACE2Binding Affinity. Nat Commun (2021) 12(1):1-9. doi: 10.1038/s41467-02121118-2

177. Daniloski Z, Jordan TX, Ilmain JK, Guo X, Bhabha G, Sanjana NE. The Spike D614G Mutation Increases SARS-CoV-2 Infection of Multiple Human Cell Types. Elife (2021) 10:e65365. doi: 10.7554/eLife.65365

178. Alenquer M, Ferreira F, Lousa D, Valério M, Medina-Lopes M, Bergman ML, et al. Signatures in SARS-CoV-2 Spike Protein Conferring Escape to Neutralizing Antibodies. PloS Pathog (2021) 17(8):e1009772. doi: 10.1371/ journal.ppat.1009772

179. Afrin SZ, Paul SK, Begum JA, Nasreen SA, Ahmed S, Ahmad FU, et al. Extensive Genetic Diversity With Novel Mutations in Spike Glycoprotein of Severe Acute Respiratory Syndrome Coronavirus 2, Bangladesh in Late 2020. New Microbes New Infect (2021) 41:100889. doi: 10.1016/j.nmni.2021.100889

180. Li X, Zhang L, Chen S, Ji W, Li C, Ren L. Recent Progress on the Mutations of SARS-CoV-2 Spike Protein and Suggestions for Prevention and Controlling of the Pandemic. Infection Genet Evol (2021) 93:104971. doi: 10.1016/ j.meegid.2021.104971

181. Thomson EC, Rosen LE, Shepherd JG, Spreafico R, da Silva Filipe A, Wojcechowskyj JA, et al. Circulating SARS-CoV-2 Spike N439K Variants Maintain Fitness While Evading Antibody-Mediated Immunity. Cell (2021) 184(5):1171-87.e1120. doi: 10.1016/j.cell.2021.01.037
182. Wang R, Chen J, Gao K, Wei G-W. Vaccine-Escape and Fast-Growing Mutations in the United Kingdom, the United States, Singapore, Spain, India, and Other COVID-19-Devastated Countries. Genomics (2021) 113 (4):2158-70. doi: 10.1016/j.ygeno.2021.05.006

183. Calvignac-Spencer S, Budt M, Huska M, Richard H, von Kleist M, Kröger S, et al. Emergence of SARS-CoV-2 Lineage A. 27 in Germany, Expressing Viral Spike Proteins With Several Amino Acid Replacements of Interest, Including L18F, L452R, and N501Y in the Absence of D614G. Viruses (2021) 15. doi: $10.3390 / \mathrm{v} 13081491$

184. Tchesnokova V, Kulakesara H, Larson L, Bowers V, Rechkina E, Kisiela D, et al. Acquisition of the L452R Mutation in the ACE2-Binding Interface of Spike Protein Triggers Recent Massive Expansion of SARS-Cov-2 Variants. bioRxiv (2021) 59:e0092121. doi: 10.1101/2021.02.22.432189

185. Lassaunière R, Fonager J, Rasmussen M, Frische A, Polacek C, Rasmussen TB, et al. In Vitro Characterization of Fitness and Convalescent Antibody Neutralization of SARS-CoV-2 Cluster 5 Variant Emerging in Mink at Danish Farms. Front Microbiol (2021) 12:1679. doi: 10.3389/fmicb. 2021.698944

186. Cai HY, Cai A. SARS-CoV2 Spike Protein Gene Variants With N501T and G142D Mutation-Dominated Infections in Mink in the United States. J Vet Diagn Invest (2021) 33:939-42. doi: 10.1101/2021.03.18.21253734

187. Everett HE, Lean FZ, Byrne AM, van Diemen PM, Rhodes S, James J, et al. Intranasal Infection of Ferrets With SARS-CoV-2 as a Model for Asymptomatic Human Infection. Viruses (2021) 13(1):113. doi: 10.3390/ v13010113

188. Focosi D, Maggi F. Neutralising Antibody Escape of SARS-CoV-2 Spike Protein: Risk Assessment for Antibody-Based Covid-19 Therapeutics and Vaccines. Rev Med Virol (2021) 31(6):e2231. doi: 10.1002/rmv.2231

189. Upadhyay V, Lucas A, Panja S, Miyauchi R, Mallela KM. Receptor Binding, Immune Escape, and Protein Stability Direct the Natural Selection of SARSCoV-2 Variants. J Biol Chem (2021) 297:101208. doi: 10.1101/2021.05. 23.445348

190. Urrutikoetxea-Gutierrez M. De Novo Emergence of the Mutation E484K in a SARS-CoV-2 B. 1.1. 7 Lineage Variant. Enferm Infec y Microbiol Clin (2021). doi: 10.1016/j.eimc.2021.07.005

191. Ferrareze PAG, Franceschi VB, de Menezes Mayer A, Caldana GD, Zimerman RA, Thompson CE. E484K as an Innovative Phylogenetic Event for Viral Evolution: Genomic Analysis of the E484K Spike Mutation in SARS-CoV-2 Lineages From Brazil. Infect Genet Evol (2021) 93:104941. doi: 10.1016/j.meegid.2021.104941

192. Jensen B, Luebke N, Feldt T, Keitel V, Brandenburger T, Kindgen-Milles D, et al. Emergence of the E484K Mutation in SARS-COV-2-Infected Immunocompromised Patients Treated With Bamlanivimab in Germany. Lancet Reg Health-Europe (2021) 8:100164. doi: 10.1016/j.lanepe.2021.100164

193. Lesho E, Corey B, Lebreton F, Ong A, Swierczewski B, Bennett J, et al. Emergence of the E484K Mutation in Severe Acute Respiratory Syndrome Coronavirus 2 (SARS-CoV-2) Lineage B.1.1.345 in Upstate New York. Clin Infect Dis (2021). doi: 10.1093/cid/ciab507

194. Sekizuka T, Itokawa K, Hashino M, Okubo K, Ohnishi A, Goto K, et al. A Discernable Increase in the Severe Acute Respiratory Syndrome Coronavirus 2 R. 1 Lineage Carrying an E484K Spike Protein Mutation in Japan. Infection Genet Evol (2021) 105013:1-4. doi: 10.1016/j.meegid.2021.105013

195. Lohr B, Niemann D, Verheyen J. Bamlanivimab Treatment Leads to Rapid Selection of Immune Escape Variant Carrying E484K Mutation in a B. 1.1. 7 Infected and Immunosuppressed Patient. Clin Infect Dis (2021) 73:2144-5. doi: 10.1093/cid/ciab392

196. Ramirez S, Fernandez-Antunez C, Galli A, Underwood A, Pham LV, Ryberg LA, et al. Overcoming Culture Restriction for SARS-CoV-2 in Human Cells Facilitates the Screening of Compounds Inhibiting Viral Replication. Antimicrob Agents Chemother (2021) AAC:00097-21. doi: 10.1128/ AAC.00097-21

197. Torrientes MS, Abietar CC, Riveiro JB, Álvarez-Argüelles M, Rojo-Alba S, Salinas FA, et al. A Novel Single Nucleotide Polymorphism Assay for the Detection of N501Y SARS-CoV-2 Variants. J Virol Methods (2021) 294:114143. doi: 10.1016/j.jviromet.2021.114143

198. Chaintoutis SC, Chassalevris T, Tsiolas G, Balaska S, Vlatakis I, Mouchtaropoulou E, et al. A One-Step Real-Time RT-PCR Assay for Simultaneous Typing of SARS-CoV-2 Mutations Associated With the 
E484K and N501Y Spike Protein Amino-Acid Substitutions. J Virol Methods (2021) 296:1-6. doi: 10.1016/j.jviromet.2021.114242

199. Li Q, Nie J, Wu J, Zhang L, Ding R, Wang H, et al. SARS-CoV-2 501y. V2 Variants Lack Higher Infectivity But do Have Immune Escape. Cell (2021) 184(9):2362-71.e2369. doi: 10.1016/j.cell.2021.02.042

200. Thoms M, Buschauer R, Ameismeier M, Koepke L, Denk T, Hirschenberger M, et al. Structural Basis for Translational Shutdown and Immune Evasion by the Nsp1 Protein of SARS-CoV-2. Science (2020) 369(6508):1249-55. doi: $10.1126 /$ science.abc8665

201. Lin J-w, Tang C, Wei H-C, Du B, Chen C, Wang M, et al. Genomic Monitoring of SARS-CoV-2 Uncovers an Nsp1 Deletion Variant That Modulates Type I Interferon Response. Cell Host Microbe (2021) 29 (3):489-502.e488. doi: 10.1016/.j.chom.2021.01.015

202. Angeletti S, Benvenuto D, Bianchi M, Giovanetti M, Pascarella S. COVID2019: The Role of the Nsp2 and Nsp3 in its Pathogenesis. J Med Virol (2020) 92(6):584-8. doi: 10.1002/jmv.25719

203. Benvenuto D, Angeletti S, Giovanetti M, Bianchi M, Pascarella S, Cauda R, et al. Evolutionary Analysis of SARS-CoV-2: How Mutation of NonStructural Protein 6 (NSP6) Could Affect Viral Autophagy. J Infect (2020) 81(1):e24-7. doi: 10.1016/j.jinf.2020.03.058

204. Majumdar P, Niyogi S. ORF3a Mutation Associated With Higher Mortality Rate in SARS-CoV-2 Infection. Epidemiol Infect (2020) 148:e262 (1-6). doi: $10.1017 /$ S0950268820002599

205. Wang R, Chen J, Gao K, Hozumi Y, Yin C, Wei G-W. Analysis of SARSCoV-2 Mutations in the United States Suggests Presence of Four Substrains and Novel Variants. Commun Biol (2021) 4(1):1-14. doi: 10.1038/s42003021-01754-6

206. Plotkin SA. Correlates of Protection Induced by Vaccination. Clin Vaccine Immunol (2010) 17(7):1055-65. doi: 10.1128/CVI.00131-10

207. Sadarangani M, Marchant A, Kollmann TR. Immunological Mechanisms of Vaccine-Induced Protection Against COVID-19 in Humans. Nat Rev Immunol (2021) 21:1-10. doi: 10.1038/s41577-021-00578-Z

208. Hoffmann M, Arora P, Groß R, Seidel A, Hörnich BF, Hahn AS, et al. SARSCoV-2 Variants B. 1.351 and P. 1 Escape From Neutralizing Antibodies. Cell (2021) 184(9):2384-93.e2312. doi: 10.1016/j.cell.2021.03.036

209. Baum A, Fulton BO, Wloga E, Copin R, Pascal KE, Russo V, et al. Antibody Cocktail to SARS-CoV-2 Spike Protein Prevents Rapid Mutational Escape Seen With Individual Antibodies. Science (2020) 369(6506):1014-8. doi: 10.1126/science.abd0831

210. Greaney AJ, Starr TN, Barnes CO, Weisblum Y, Schmidt F, Caskey M, et al. Mapping Mutations to the SARS-CoV-2 RBD That Escape Binding by Different Classes of Antibodies. Nat Commun (2021) 12(1):1-14. doi: $10.1038 / s 41467-021-24435-8$

211. Starr TN, Greaney AJ, Dingens AS, Bloom JD. Complete Map of SARS-CoV2 RBD Mutations That Escape the Monoclonal Antibody LY-CoV555 and its Cocktail With LY-Cov016. Cell Rep Med (2021) 2(4):100255. doi: 10.1016/ j.xcrm.2021.100255

212. Liu Z, VanBlargan LA, Bloyet L-M, Rothlauf PW, Chen RE, Stumpf S, et al. Identification of SARS-CoV-2 Spike Mutations That Attenuate Monoclonal and Serum Antibody Neutralization. Cell Host Microbe (2021) 29(3):47788.e474. doi: 10.1016/j.chom.2021.01.014

213. Starr TN, Czudnochowski N, Liu Z, Zatta F, Park Y-J, Addetia A, et al. SARSCoV-2 RBD Antibodies That Maximize Breadth and Resistance to Escape. Nature (2021) 597(7874):97-102. doi: 10.1038/s41586-021-03807-6

214. Greaney AJ, Loes AN, Crawford KH, Starr TN, Malone KD, Chu HY, et al. Comprehensive Mapping of Mutations in the SARS-CoV-2 ReceptorBinding Domain That Affect Recognition by Polyclonal Human Plasma Antibodies. Cell Host Microbe (2021) 29(3):463-76.e466. doi: 10.1016/ j.chom.2021.02.003

215. Yuan M, Liu H, Wu NC, Wilson IA. Recognition of the SARS-CoV-2 Receptor Binding Domain by Neutralizing Antibodies. Biochem Biophys Res Commun (2021) 538:192-203. doi: 10.1016/j.bbrc.2020.10.012

216. Jovčevska I, Muyldermans S. The Therapeutic Potential of Nanobodies. BioDrugs (2020) 34(1):11-26. doi: 10.1007/s40259-019-00392-z

217. Cheloha RW, Harmand TJ, Wijne C, Schwartz TU, Ploegh HL. Exploring Cellular Biochemistry With Nanobodies. J Biol Chem (2020) 295(45):1530727. doi: 10.1074/jbc.REV120.012960
218. Bessalah S, Jebahi S, Mejri N, Salhi I, Khorchani T, Hammadi M. Perspective on Therapeutic and Diagnostic Potential of Camel Nanobodies for Coronavirus Disease-19 (COVID-19). 3 Biotech (2021) 11(2):1-14. doi: 10.1007/s13205-021-02647-5

219. Xiang Y, Nambulli S, Xiao Z, Liu H, Sang Z, Duprex WP, et al. Versatile and Multivalent Nanobodies Efficiently Neutralize SARS-CoV-2. Science (2020) 370(6523):1479-84. doi: 10.1126/science.abe4747

220. Sun Z, Chen C, Li W, Martinez DR, Drelich A, Baek DS, et al. Potent Neutralization of SARS-CoV-2 by Human Antibody Heavy-Chain Variable Domains Isolated From a Large Library With a New Stable Scaffold. In: MAbs (2020) 12(1):1778435. doi: 10.1080/19420862.2020.1778435

221. Wu Y, Li C, Xia S, Tian X, Kong Y, Wang Z, et al. Identification of Human Single-Domain Antibodies Against SARS-CoV-2. Cell Host Microbe (2020) 27(6):891-8. doi: 10.1016/j.chom.2020.04.023

222. Koenig PA, Das H, Liu H, Kümmerer BM, Gohr FN, Jenster LM, et al. Structure-Guided Multivalent Nanobodies Block SARS-CoV-2 Infection and Suppress Mutational Escape. Science (2021) 371(6530):1-15. doi: 10.1126/ science.abe6230

223. Duan K, Liu B, Li C, Zhang H, Yu T, Qu J, et al. Effectiveness of Convalescent Plasma Therapy in Severe COVID-19 Patients. Proc Natl Acad Sci (2020) 117 (17):9490-6. doi: 10.1073/pnas.2004168117

224. Volk A, Covini-Souris C, Kuehnel D, De Mey C, Römisch J, Schmidt T. SARS-CoV-2 Neutralization in Convalescent Plasma and Commercial Lots of Plasma-Derived Immunoglobulin. BioDrugs (2021) 1-13. doi: 10.1007/ s40259-021-00511-9

225. Simonovich VA, Burgos Pratx LD, Scibona P, Beruto MV, Vallone MG, Vázquez C, et al. A Randomized Trial of Convalescent Plasma in Covid-19 Severe Pneumonia. New Engl J Med (2021) 384(7):619-29. doi: 10.1056/ NEJMoa2031304

226. Fazeli A, Sharifi S, Behdad F, Okati S, Esmaielifar G, Jelveh N, et al. Early High-Titer Convalescent Plasma Therapy in Patients With Moderate and Severe COVID-19. Transfusion Apher Sci (2021) 103321. doi: 10.1016/ j.transci.2021.103321

227. Cele S, Gazy I, Jackson L, Hwa SH, Tegally H, Lustig G, et al. Escape of SARSCoV-2 501y. V2 From Neutralization by Convalescent Plasma. Nature (2021) 593(7857):142-6. doi: 10.1038/s41586-021-03471-w

228. Callaway E. Could New COVID Variants Undermine Vaccines? Labs Scramble to Find Out. Nature (2021) 589(7841):177-8. doi: 10.1038/ d41586-021-00031-0

229. Rubin R. COVID-19 Vaccines vs Variants-Determining How Much Immunity Is Enough. Jama (2021) 325(13):1241-3. doi: 10.1001/jama. 2021.3370

230. Chen RE, Zhang X, Case JB, Winkler ES, Liu Y, VanBlargan LA, et al. Resistance of SARS-CoV-2 Variants to Neutralization by Monoclonal and Serum-Derived Polyclonal Antibodies. Nat Med (2021) 27(4):717-26. doi: 10.1038/s41591-021-01294-w

231. Bian L, Gao F, Zhang J, He Q, Mao Q, Xu M, et al. Effects of SARS-CoV-2 Variants on Vaccine Efficacy and Response Strategies. Expert Rev Vaccines (2021) 20:1-9. doi: 10.1080/14760584.2021.1903879

232. Shinde V, Bhikha S, Hoosain Z, Archary M, Bhorat Q, Fairlie L, et al. Efficacy of NVX-CoV2373 Covid-19 Vaccine Against the B. 1.351 Variant. N Engl J Med (2021) 384(20):1899-909. doi: 10.1056/NEJMoa2103055

233. Madhi SA, Baillie V, Cutland CL, Voysey M, Koen AL, Fairlie L, et al. Efficacy of the ChAdOx1 Ncov-19 Covid-19 Vaccine Against the B. 1.351 Variant. $N$ Engl J Med (2021) 384(20):1885-98.doi: 10.1056/NEJMoa2102214

234. Muik A, Wallisch A-K, Sänger B, Swanson KA, Mühl J, Chen W, et al. Neutralization of SARS-CoV-2 Lineage B. 1.1. 7 Pseudovirus by BNT162b2 Vaccine-Elicited Human Sera. Science (2021) 371(6534):1152-3. doi: $10.1126 /$ science.abg6105

235. Wang Z, Schmidt F, Weisblum Y, Muecksch F, Barnes CO, Finkin S, et al. mRNA Vaccine-Elicited Antibodies to SARS-CoV-2 and Circulating Variants. Nature (2021) 592(7855):616-22. doi: 10.1038/s41586-02103324-6

236. Supasa P, Zhou D, Dejnirattisai W, Liu C, Mentzer AJ, Ginn HM, et al. Reduced Neutralization of SARS-CoV-2 B. 1.1. 7 Variant by Convalescent and Vaccine Sera. Cell (2021) 184(8):2201-11.e2207. doi: 10.1016/ j.cell.2021.02.033 
237. Zhou D, Dejnirattisai W, Supasa P, Liu C, Mentzer AJ, Ginn HM, et al. Evidence of Escape of SARS-CoV-2 Variant B. 1.351 From Natural and Vaccine-Induced Sera. Cell (2021) 1842348-2361(9):e2346. doi: 10.1016/ j.cell.2021.02.037

238. Huang B, Dai L, Wang H, Hu Z, Yang X, Tan W, et al. Serum Sample Neutralisation of BBIBP-CorV and ZF2001 Vaccines to SARS-CoV-2 501y. V2. Lancet Microbe (2021) 2(7):e285. doi: 10.1016/S2666-5247(21)00082-3

239. Noor R. Developmental Status of the Potential Vaccines for the Mitigation of the COVID-19 Pandemic and a Focus on the Effectiveness of the PfizerBioNTech and Moderna mRNA Vaccines. Curr Clin Microbiol Rep (2021), 1-8. doi: 10.1007/s40588-021-00162-y

240. Nanduri S, Pilishvili T, Derado G, Soe MM, Dollard P, Wu H, et al. Effectiveness of Pfizer-BioNTech and Moderna Vaccines in Preventing SARS-CoV-2 Infection Among Nursing Home Residents Before and During Widespread Circulation of the SARS-CoV-2 B. 1.617. 2 (Delta) Variant-National Healthcare Safety Network, March 1-August 1, 2021. Morbid Mortal Weekly Rep (2021) 70(34):1163. doi: 10.15585/mmwr. $\mathrm{mm} 7034 \mathrm{e} 3$

241. Chakraborty C, Sharma AR, Bhattacharya M, Lee SS. From COVID-19 to Cancer mRNA Vaccines: Moving From Bench to Clinic in the Vaccine Landscape. Front Immunol (2021) 12:2648. doi: 10.3389/fimmu.2021.679344

242. Chakraborty C, Sharma AR, Bhattacharya M, Sharma G, Saha RP, Lee SS. Ongoing Clinical Trials of Vaccines to Fight Against COVID-19 Pandemic. Immune Netw (2021) 21(1):1-22. doi: 10.4110/in.2021.21.e5

243. Garcia-Beltran WF, Lam EC, Denis KS, Nitido AD, Garcia ZH, Hauser BM, et al. Multiple SARS-CoV-2 Variants Escape Neutralization by VaccineInduced Humoral Immunity. Cell (2021) 184(9):2372-83. doi: 10.1016/ j.cell.2021.03.013

244. Carreño JM, Alshammary H, Singh G, Raskin A, Amanat F, Amoako A, et al. Evidence for Retained Spike-Binding and Neutralizing Activity Against Emerging SARS-CoV-2 Variants in Serum of COVID-19 mRNA Vaccine Recipients. EBioMedicine (2021) 73103626. doi: 10.1016/j.ebiom. 2021.103626

245. Martínez-Flores D, Zepeda-Cervantes J, Cruz-Reséndiz A, Aguirre-Sampieri S, Sampieri A, Vaca L. SARS-CoV-2 Vaccines Based on the Spike Glycoprotein and Implications of New Viral Variants. Front Immunol (2021) 12:701501. doi: 10.3389/fimmu.2021.701501

246. Salvatori G, Luberto L, Maffei M, Aurisicchio L, Roscilli G, Palombo F, et al. SARS-CoV-2 Spike Protein: An Optimal Immunological Target for Vaccines. J Trans Med (2020) 18(1):222. doi: 10.1186/s12967-020-02392-y

247. Saha RP, Sharma AR, Singh MK, Samanta S, Bhakta S, Mandal S, et al. Repurposing Drugs, Ongoing Vaccine, and New Therapeutic Development Initiatives Against COVID-19. Front Pharmacol (2020) 11:1258. doi: 10.3389/fphar.2020.01258

248. Rab S, Afjal MJ, Haleem A, Vaishya R. An Update on the Global Vaccine Development for Coronavirus. Diabetes Metab Syndr (2020) 14(6):2053. doi: 10.1016/j.dsx.2020.10.023

249. Andreadakis Z, Kumar A, Román RG, Tollefsen S, Saville M, Mayhew S. The COVID-19 Vaccine Development Landscape. Nat Rev Drug Discov (2020) 19 (5):305-6.

250. Bhattacharya M, Sharma AR, Patra P, Ghosh P, Sharma G, Patra BC, et al. Development of Epitope-Based Peptide Vaccine Against Novel Coronavirus 2019 (SARS-COV-2): Immunoinformatics Approach. J Med Virol (2020) 92 (6):618-31. doi: 10.1002/jmv.25736

251. Bhattacharya M, Sharma AR, Patra P, Ghosh P, Sharma G, Patra BC, et al. A SARS-CoV-2 Vaccine Candidate: In-Silico Cloning and Validation. Inf Med Unlocked (2020) 20:100394. doi: 10.1016/j.imu.2020.100394

252. Chakraborty C, Sharma AR, Bhattacharya M, Sharma G, Lee SS. Immunoinformatics Approach for the Identification and Characterization of T Cell and B Cell Epitopes Towards the Peptide-Based Vaccine Against SARS-CoV-2. Arch Med Res (2021) 52(4):362-70. doi: 10.1016/j.arcmed. 2021.01.004

253. Chakraborty C, Sharma AR, Bhattacharya M, Lee SS. Lessons Learned From Cutting-Edge Immunoinformatics on Next-Generation COVID-19 Vaccine Research. Int J Pept Res Ther (2021) 27(4):2303-11. doi: 10.1007/s10989021-10254-4

254. Rakib A, Sami SA, Mimi NJ, Chowdhury MM, Eva TA, Nainu F, et al. Immunoinformatics-Guided Design of an Epitope-Based Vaccine Against
Severe Acute Respiratory Syndrome Coronavirus 2 Spike Glycoprotein. Comput Biol Med (2020) 124:103967. doi: 10.1016/j.compbiomed.2020.103967

255. Bhattacharya M, Sharma AR, Ghosh P, Lee SS, Chakraborty C. A NextGeneration Vaccine Candidate Using Alternative Epitopes to Protect Against Wuhan and All Significant Mutant Variants of SARS-CoV-2: An Immunoinformatics Approach. Aging Dis (2021) 12(8):2173-95. doi: 10.14336/AD.2021.0518

256. Gavor E, Choong YK, Er SY, Sivaraman H, Sivaraman J. Structural Basis of SARS-CoV-2 and SARS-CoV-antibody Interactions. Trends Immunol (2020) 41(11):1006-22. doi: 10.1016/j.it.2020.09.004

257. Ku Z, Xie X, Davidson E, Ye X, Su H, Menachery VD, et al. Molecular Determinants and Mechanism for Antibody Cocktail Preventing SARSCoV-2 Escape. Nat Commun (2021) 12(1):469. doi: 10.1038/s41467-02020789-7

258. Chakraborty C, Bhattacharya M, Sharma AR. Emerging Mutations in the SARS-CoV-2 Variants and Their Role in Antibody Escape to Small Molecule-Based Therapeutic Resistance. Curr Opin Pharmacol (2021) 62:64-73. doi: 10.1016/j.coph.2021.11.006

259. Chakraborty C, Sharma AR, Bhattacharya M, Agoramoorthy G, Lee SS. The Drug Repurposing for COVID-19 Clinical Trials Provide Very Effective Therapeutic Combinations: Lessons Learned From Major Clinical Studies. Front Pharmacol (2021) 12:704205. doi: 10.3389/fphar.2021.704205

260. Singh TU, Parida S, Lingaraju MC, Kesavan M, Kumar D, Singh RK. Drug Repurposing Approach to Fight COVID-19. Pharmacol Rep (2020) 72 (6):1479-508. doi: 10.1007/s43440-020-00155-6

261. Chakraborty C, Sharma AR, Sharma G, Bhattacharya M, Lee SS. SARS-CoV2 Causing Pneumonia-Associated Respiratory Disorder (COVID-19): Diagnostic and Proposed Therapeutic Options. Eur Rev Med Pharmacol Sci (2020) 24(7):4016-26. doi: 10.26355/eurrev_202004_20871

262. Chakraborty C, Bhattacharya M, Mallick B, Sharma AR, Lee SS, Agoramoorthy G. SARS-CoV-2 Protein Drug Targets Landscape: A Potential Pharmacological Insight View for the New Drug Development. Expert Rev Clin Pharmacol (2021) 14(2):225-37. doi: 10.1080/17512433. 2021.1874348

263. Neumann-Haefelin C, Blum HE, Chisari FV, Thimme R. T Cell Response in Hepatitis C Virus Infection. J Clin Virol (2005) 32(2):75-85. doi: 10.1016/ j.jcv.2004.05.008

264. Sanchez-Merino V, Nie S, Luzuriaga K. HIV-1-Specific CD8+ T Cell Responses and Viral Evolution in Women and Infants. J Immunol (2005) 175(10):6976-86. doi: 10.4049/jimmunol.175.10.6976

265. Geers D, Shamier MC, Bogers S, den Hartog G, Gommers L, Nieuwkoop NN, et al. SARS-CoV-2 Variants of Concern Partially Escape Humoral But Not T Cell Responses in COVID-19 Convalescent Donors and Vaccine Recipients. Sci Immunol (2021) 6(59):eabj1750. doi: 10.1126/sciimmunol.abj1750

266. Callaway E. Heavily Mutated Omicron Variant Puts Scientists on Alert. Nature (2021) 600(7887):21-1. doi: 10.1038/d41586-021-03552-w

267. Song Y, Masaki F. Preparation for the Challenge of Heavily Mutated Omicron Variant. Clin Trans Med (2021) 11(12):e679 (1-2). doi: 10.1002/ctm2.679

268. Barton MI, MacGowan SA, Kutuzov MA, Dushek O, Barton GJ, van der Merwe PA. Effects of Common Mutations in the SARS-CoV-2 Spike RBD and its Ligand, the Human ACE2 Receptor on Binding Affinity and Kinetics. Elife (2021) 10:e70658. doi: 10.7554/eLife.70658

269. Salleh MZ, Derrick JP, Deris ZZ. Structural Evaluation of the Spike Glycoprotein Variants on SARS-CoV-2 Transmission and Immune Evasion. Int J Mol Sci (2021) 22(14):7425. doi: 10.3390/ijms22147425

270. Bhattacharya M, Chatterjee S, Sharma AR, Agoramoorthy G, Chakraborty C. D614G Mutation and SARS-CoV-2: Impact on S-Protein Structure, Function, Infectivity, and Immunity. Appl Microbiol Biotechnol (2021) 105 (24):9035-45. doi: 10.1007/s00253-021-11676-2

271. Rio DL, Omer SB, Malani PN. Winter of Omicron-The Evolving COVID-19 Pandemic. J Am Med Assoc (2021). doi: 10.1001/jama.2021.24315

272. Chakraborty C, Sharma AR, Bhattacharya M, Agoramoorthy G, Lee S-S. A Paradigm Shift in the Combination Changes of SARS-CoV-2 Variants and Increased Spread of Delta Variant (B.1.617.2) Across the World. Aging Dis (2021). doi: 10.14336/AD.2021.1117

273. Cao YR, Wang J, Jian F, Xiao T, Song W, Yisimayi A, et al. Omicron Escapes the Majority of Existing SARS-CoV-2 Neutralizing Antibodies. Nature (2021). doi: 10.1038/s41586-021-04385-3 
274. Burki TK. Omicron Variant and Booster COVID-19 Vaccines. Lancet Respir Med (2021) S2213-2600(21)00559-2. doi: 10.1016/S2213-2600(21)00559-2

275. Cohen J. Omicron Sparks a Vaccine Strategy Debate. Science (2021) 374 (6575):1544-5. doi: 10.1126/science.acz9879

276. Li X. Omicron: Call for Updated Vaccines. J Med Virol (2021). doi: 10.1002/ jmv. 27530

277. Chakraborty C, Sharma AR, Sharma G, Bhattacharya M, Saha RP. Extensive Partnership, Collaboration, and Teamwork is Required to Stop the COVID-19 Outbreak. Arch Med Res (2020) 51(7):728-30. doi: 10.1016/j.arcmed.2020.05.021

Conflict of Interest: The authors declare that the research was conducted in the absence of any commercial or financial relationships that could be construed as a potential conflict of interest.
Publisher's Note: All claims expressed in this article are solely those of the authors and do not necessarily represent those of their affiliated organizations, or those of the publisher, the editors and the reviewers. Any product that may be evaluated in this article, or claim that may be made by its manufacturer, is not guaranteed or endorsed by the publisher.

Copyright (๑) 2022 Chakraborty, Sharma, Bhattacharya and Lee. This is an openaccess article distributed under the terms of the Creative Commons Attribution License (CC BY). The use, distribution or reproduction in other forums is permitted, provided the original author(s) and the copyright owner(s) are credited and that the original publication in this journal is cited, in accordance with accepted academic practice. No use, distribution or reproduction is permitted which does not comply with these terms. 